Article

\title{
Environmental Reactions of Air-Quality Protection on Eco-Friendly Iron-Based Catalysts
}

\author{
Melissa Greta Galloni ${ }^{1,+} \oplus$, Sebastiano Campisi ${ }^{1,+} \oplus$, Sergio Gustavo Marchetti ${ }^{2}$ \\ and Antonella Gervasini ${ }^{1, *(\mathbb{D})}$ \\ 1 Dipartimento di Chimica, Università degli Studi di Milano, via Camillo Golgi 19, 20133 Milano, Italy; \\ melissa.galloni@unimi.it (M.G.G.); sebastiano.campisi@unimi.it (S.C.) \\ 2 Centro de Investigación y Desarrollo en Procesos Catalíticos, CINDECA (UNLP-CONICET), \\ Calle 47 No. 257, La Plata C.P. 1900, Argentina; march@quimica.unlp.edu.ar \\ * Correspondence: antonella.gervasini@unimi.it; Tel.: +39-02-5031-4254 \\ + These authors contributed equally to the work.
}

Received: 16 November 2020; Accepted: 29 November 2020; Published: 3 December 2020

check for

\begin{abstract}
A series of iron functionalized hydroxyapatite (Fe/HAP) samples with different metal loading $(2<\mathrm{wt} . \% \mathrm{Fe}<13)$ was prepared by a flash ionic exchange procedure from iron(III) nitrate as precursor and tested in some environmental air-quality protection reactions such as the catalytic reduction of $\mathrm{NO}_{x}$ by $\mathrm{NH}_{3}\left(\mathrm{NH}_{3}-\mathrm{SCR}\right)$, catalytic oxidation of $\mathrm{NH}_{3}\left(\mathrm{NH}_{3}-\mathrm{SCO}\right)$ and catalytic $\mathrm{N}_{2} \mathrm{O}$ decomposition. The catalytic performances of the Fe/HAP catalysts were determined under flow conditions as a function of temperature and using reactant concentrations typical of polluting gaseous emissions from industrial vents. Physico-chemical characterization with various techniques of study (UV-DR and Mössbauer spectroscopies, $\mathrm{NH}_{3}$ titration, $\mathrm{N}_{2}$-physisorption, and XRPD analyses) provided valuable information on Fe-speciation, acidity, morphology, and structure of the samples. In general, highly dispersed $\mathrm{Fe}^{3+}$ centers were the predominant species, irrespective of Fe-loading, while just low percentage $(\leq 15 \%)$ of $\mathrm{Fe}_{x} \mathrm{O}_{y}$ nanoclusters $(2<$ size/nm $<4)$ was detected on the samples. As expected, the differences in iron concentration produced a diversified effect of both catalyst properties and catalytic activity, comprising the conversion and selectivity profiles, different for each reaction considered. The obtained results indicate a good potentiality for the eco-friendly Fe-catalysts for some environmental reactions of air protection.
\end{abstract}

Keywords: Iron-hydroxyapatite; $\mathrm{NH}_{3}-\mathrm{SCR} ; \mathrm{NH}_{3}-\mathrm{SCO} ; \mathrm{N}_{2} \mathrm{O}$ decomposition; catalyst preparation; catalyst characterization; Mössbauer spectroscopy

\section{Introduction}

The selective catalytic reduction of $\mathrm{NO}_{x}$ to harmless $\mathrm{N}_{2}$ in the presence of $\mathrm{NH}_{3}$ as reducing agent $\left(\mathrm{NH}_{3}\right.$-SCR) is currently the most effective and popular post-combustion technology for the de-nitration of flue gases [1,2]. The ideal SCR catalyst must satisfy some relevant practical requirements: (i) be effective in selectively converting $\mathrm{NO}_{x}$ over a wide temperature range [3]; (ii) ensure high thermal stability and long life in the reaction even under harsh operative conditions [4,5]; (iii) cope with poisoning by some upstream components (e.g., water, sulfur, phosphorus, alkaline metals, etc.) [6-8].

At the current state, vanadium-based systems (e.g., $\mathrm{V}_{2} \mathrm{O}_{5} / \mathrm{TiO}_{2}$ ) [9] and $\mathrm{Fe}$ - and Cu-zeolites [10] are the most popular commercial $\mathrm{NH}_{3}$-SCR catalysts for applications to stationary and mobile sources. Despite their successful and widespread use, these catalytic systems suffer from some relevant limitations and, furthermore, they may not live up to the more stringent regulations in a future scenario calling for zero-emissions to be attained. The need to strike a balance between practical constraints, economic forces, and sustainability principles is thus fueling the demand for a new generation of more 
efficient, flexible to wide operative applications, and environmentally friendly catalysts to maximize $\mathrm{NO}_{x}$ removal and further reduce the cost and footprint of SCR process.

Owing to its interesting physical and chemical properties, hydroxyapatite $\left(\mathrm{HAP}, \mathrm{Ca}_{10}\left(\mathrm{PO}_{4}\right)_{6}(\mathrm{OH})_{2}\right)$ is an attractive candidate as material for environmental remediation [11], already well exploited in biomedical and wastewater treatment $[12,13]$ fields. HAP is a well-known inorganic biomaterial that can be extracted from mineral rocks, biogenic products (e.g., eggshells, mussel shells) and bio-wastes (e.g., fish bones, mammal bones) [14]. Recently, hydroxyapatite-based materials were also obtained as the main products of NOVOSOL ${ }^{\circledR}$ process, a patented procedure developed by Solvay and aimed at treating polluted sediments [15]. Alternatively, HAP can be sourced from synthetic routes, which usually imply wet chemical methods (precipitation, sol-gel technique, hydrolysis, hydrothermal, emulsion method) starting from cheap inorganic precursors (e.g., calcium hydroxide, calcium nitrate, phosphoric acid, ammonium phosphate) $[14,16,17]$.

Besides being easily available from economically viable and safe synthetic or natural approaches, HAP is characterized by remarkable thermal stability, allowing to be processed at very high temperature (up to $800^{\circ} \mathrm{C}$ ) without significant modifications in composition and textural/morphological properties. These features account for the successful application of HAP as support for metal active phases in some catalytic gas-phase reactions. HAP functionalization with metal species could lead to multifunctional catalysts that would benefit from the combination of the electron transfer capacity and Lewis acidity associated with the metal centers and of the amphoteric surface properties of HAP. Actually, hydroxyapatite surface exposes a large variety of functional groups, acting as acid and basic sites and conferring a peculiar amphoteric character, which can be more or less pronounced depending on the HAP composition, in particular on the $\mathrm{Ca} / \mathrm{P}$ ratio [18].

Although HAP-based catalysts for environmental protection reactions have not received yet the attention they deserve, in the last years studies on several Me/HAP catalysts $(\mathrm{Me}=\mathrm{Au}, \mathrm{Pd}, \mathrm{Rh}$, $\mathrm{Co}, \mathrm{Mn}, \mathrm{Cu}, \mathrm{Fe}$, etc.) have confirmed their effectiveness in several air pollution control reactions, such as the abatement of volatile organic compounds (de-VOCs) and denitrification (de- $\mathrm{NO}_{x}$ ) processes. For instance, Chlala et al. demonstrated that palladium [19] and manganese [20] supported on HAP are more active in total oxidation of toluene than the same metal species supported on alumina. Similar evidence was shown by Boukha et al. [21], who compared the catalytic performances of $\mathrm{Pd} / \mathrm{HAP}$ and $\mathrm{Pd} /$ alumina catalysts in methane oxidation. Analogously, highly dispersed cobalt species on HAP showed improved catalytic performances in 1,2-dichloroethane oxidation compared to bulk cobalt oxide [22], while the addition of HAP to ceria support increased gold nanoparticle stability preventing their sintering at high temperature [23]. In all these cases, the observed enhancement in the catalytic performances derived both from a stabilizing effect of the HAP structure, whose surface functional groups act as anchoring sites for metal species, and the direct involvement of surface acid/base sites in the reaction mechanism.

The pioneer works of Kumar et al. [24] and Tounsi et al. [25] highlighted the potential of apatitic materials as supports for the selective catalytic reduction of $\mathrm{NO}_{x}$. Well-dispersed $\mathrm{Ag}_{2} \mathrm{O}$ and $\mathrm{CuO}$ phases on HAP surface proved to be effective in the $\mathrm{NO}_{x}$ reduction to $\mathrm{N}_{2}$, also at low temperature, in the $\mathrm{SCR}$ process by propene and $\mathrm{NH}_{3}$, respectively.

More recently, our group has investigated the hydroxyapatite functionalization with $\mathrm{Cu}$ and Fe species to obtain effective catalysts for $\mathrm{NH}_{3}$-SCR reactions [26-28]. The experimental conditions adopted during the functionalization strongly affected the sitting, local environment, and structure of metal phase. In particular, in the case of copper, highly dispersed $\mathrm{Cu}$ centers could be allocated on HAP surface up to $6 \mathrm{wt} . \%$ metal loading, while higher loading resulted in copper aggregation [28] and/or growth of crystalline libethenite phase $\left(\mathrm{Cu}_{2} \mathrm{PO}_{4} \mathrm{OH}\right)$ [25]. In addition, the copper salt used as metal phase precursor (e.g., nitrate, chloride and acetate) played a key role in inducing changes in textural properties and surface composition, which unavoidably influenced the catalytic behavior [28]. In the case of Fe-loaded hydroxyapatite (Fe/HAP), great attention has been devoted to develop a deposition technique able to assure high metal dispersion with controlled nuclearity of iron species and limited 
aggregation [26]. An innovative flash ion exchange procedure, characterized by an acidic solution containing the Fe-salt and very short contact time with HAP, has demonstrated its effectiveness in highly dispersing and stabilizing iron in the form of isolated or oligonuclear species on the surface. Although Fe/HAP catalysts showed lower activity than $\mathrm{Cu} / \mathrm{HAP}$ catalysts, the former worked in a broader operating temperature window $\left(275-450^{\circ} \mathrm{C}\right)$ [27]. In addition, the use of iron would result in less expensive and cost-efficient catalysts compared to $\mathrm{Cu}$-based ones.

In this work, we explored in a larger perspective the potential of Fe/HAP catalyst. The preparation of a series of samples with iron loading from $2 \%$ to $13 \%$ by weight by flash ion exchange was carried out. They were then tested in three distinct air-quality protection reactions: catalytic reduction of $\mathrm{NO}_{x}$ by $\mathrm{NH}_{3}\left(\mathrm{NH}_{3}-\mathrm{SCR}\right)$, selective catalytic oxidation of $\mathrm{NH}_{3}\left(\mathrm{NH}_{3}-\mathrm{SCO}\right)$ and catalytic $\mathrm{N}_{2} \mathrm{O}$ decomposition. The latter two reactions, besides being largely used to control the emissions of the $\mathrm{NH}_{3}$ and $\mathrm{N}_{2} \mathrm{O}$ polluting species from industrial productions (e.g., $\mathrm{NH}_{3}$ from ammonium phosphate manufacture or $\mathrm{N}_{2} \mathrm{O}$ from adipic acid synthesis), can be also coupled to $\mathrm{NH}_{3}-\mathrm{SCR}$ process in cascade to solve the problem of ammonia slipping and unselective reduction of $\mathrm{NO}_{x}\left(\right.$ to $\mathrm{N}_{2} \mathrm{O}$ ). The catalytic behavior of the $\mathrm{Fe} / \mathrm{HAP}$ catalysts in these reactions will be discussed in relation to the surface acidity and iron dispersion of the catalysts together with other relevant morphological and structural features.

\section{Results}

Iron phase was supported on hydroxyapatite with concentration in a wide range $(2<\mathrm{wt} . \%$ $\mathrm{Fe}<13)$ according to a flash ion exchange procedure, already presented in the literature [26,27]. In this procedure the operative $\mathrm{pH}$ (ca. 3) and contact time (15 min) of HAP and Fe-salt precursor have been properly selected with the intent of depositing highly dispersed iron species on HAP, achieving a compromise between the complex iron speciation in aqueous solution (iron tends to precipitate at $\mathrm{pH}>3$ ) and the $\mathrm{pH}$-sensitive interfacial properties of HAP [29]. Indeed, hydrated HAP surfaces generate a complex interphase layer whose thickness, composition, and charge distribution depend mainly on $\mathrm{pH}$ [30-32].

The properties of as-prepared iron-containing samples (labelled as $\mathrm{FeX} / \mathrm{HAP}_{\mathrm{IE}}$ where $\mathrm{X}$ is the iron loading as $\mathrm{wt} . \%$ ) are presented in Table 1. The determination of iron content (by atomic absorption spectroscopy) confirmed that iron was quantitatively immobilized on HAP even at relatively high loading (13 wt.\%), despite the very short contact time. The latter should permit preserving, largely, the pristine structural and morphological features of HAP, which is known to suffer from acidic environment.

Table 1. Main morphological and surface properties of all the Fe/HAP samples compared with those of bare HAP calcined at $500{ }^{\circ} \mathrm{C}$.

\begin{tabular}{|c|c|c|c|c|c|c|}
\hline Code & $\begin{array}{c}\text { Fe Loading a } \\
\text { (wt. } \%)\end{array}$ & $\begin{array}{l}\text { S.A. } \\
\left(\mathrm{m}^{2} \cdot \mathrm{g}^{-1}\right)\end{array}$ & $\begin{array}{l}\text { Pore Volume } \\
\quad\left(\mathrm{cm}^{3} \cdot \mathrm{g}^{-1}\right)\end{array}$ & $\begin{array}{c}\text { Mean Pore } \\
\text { Radius }^{\mathrm{d}}(\mathrm{nm})\end{array}$ & $\begin{array}{c}\text { Acidity } \\
\left(\mu \mathrm{mol}_{\mathrm{NH} 3(\mathrm{ads})} \cdot \mathrm{g}^{-1}\right)\end{array}$ & $\begin{array}{l}\text { Acidity } \\
\text { Ratio }\end{array}$ \\
\hline $\mathrm{HAP} / 500^{\mathrm{f}}$ & - & 44 & 0.19 & 8.2 & 140.5 & - \\
\hline $\mathrm{Fe} 3 / \mathrm{HAP}_{\mathrm{IE}}$ & 3.02 & 64 & 0.22 & 7.4 & $167.4 \pm 12$ & 1.19 \\
\hline $\mathrm{Fe} 5 / \mathrm{HAP}_{\mathrm{IE}}$ & 4.77 & 66 & 0.20 & 6.4 & $206.7 \pm 7.3$ & 1.47 \\
\hline $\mathrm{Fe} 13 / \mathrm{HAP}_{\mathrm{IE}}$ & 12.93 & 82 & 0.30 & 5.6 & $262.4 \pm 7.3$ & 1.87 \\
\hline
\end{tabular}

${ }^{\mathrm{a}}$ obtained by atomic absorption on solid after mineralization (see Experimental section); ${ }^{\mathrm{b}}$ Surface Area (S.A.) determined by BET equation (2-parameters); ${ }^{\mathrm{c}}$ at $\mathrm{p} / \mathrm{p}^{0}=0.95{ }^{\mathrm{d}}$ determined by Barrett-Joyner-Halenda (BJH) model from desorption branch of the isotherm $\left(0.3<\mathrm{p} / \mathrm{p}^{0}<0.95\right)$; ${ }^{\mathrm{e}}$ sample acidity ratio compared with that of bare HAP; ${ }^{\mathrm{f}}$ bare HAP calcined at $500^{\circ} \mathrm{C}$ for $1 \mathrm{~h}$.

Pristine HAP was a crystalline solid (Figure S1) with moderate surface area value $\left(44 \mathrm{~m}^{2} \cdot \mathrm{g}^{-1}\right)$, pore volume of ca. $0.19 \mathrm{~cm}^{3} \cdot \mathrm{g}^{-1}$ and mesopores with size distribution centered at around $8.2 \mathrm{~nm}$. The $\mathrm{N}_{2}$-adsorption/desorption isotherm showed the hysteresis loop typical of mesoporous materials with broad pore structure [33]. The mesoporosity of HAP was maintained also after the introduction of 
iron whatever the content (Figure S1b,c). An interesting trend was detected in the surface area values (S.A., Table 1): a small iron amount produced a significant increase $\left(67 \mathrm{~m}^{2} \cdot \mathrm{g}^{-1}\right.$ for Fe2/HAP $\left.\mathrm{IE}\right)$ in S.A. value, which finally almost doubled in the sample containing the highest Fe loading $\left(82 \mathrm{~m}^{2} \cdot \mathrm{g}^{-1}\right.$ for $\left.\mathrm{Fe} 13 / \mathrm{HAP}_{\mathrm{IE}}\right)$. These morphological changes can be ascribed to surface rearrangement induced by the iron species distributed on HAP surface as nanosized aggregates or amorphous phases.

X-ray powder diffraction (XRPD) patterns of Fe-loaded HAP samples (Figure 1) presented exclusively the typical reflections of crystalline HAP and no additional iron-containing crystal phases can be inferred. Consequently, the formation of separate iron oxide aggregates can be ruled out, thus suggesting that iron was highly dispersed as isolated ions/small-sized nanoclusters on HAP surface as an amorphous phase or as nanocrystalline aggregates below the detection size limit of the XRPD. It is noteworthy that the overall intensity of the XRD peaks of Fe/HAP samples (Figure 1) decreased as the iron concentration increased, and this evidence might suggest that a partial amorphization of the samples occurred.

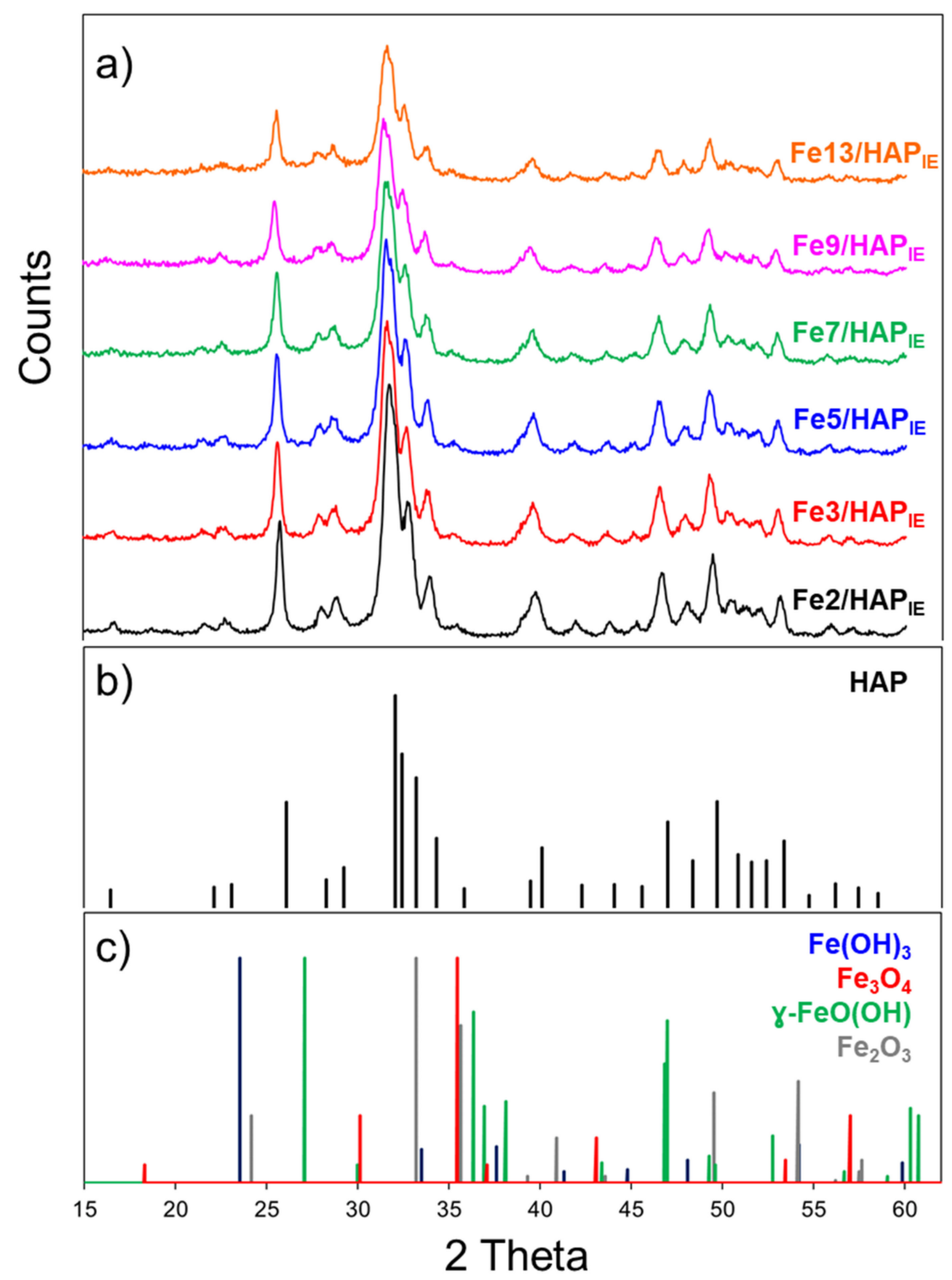

Figure 1. XRPD patterns of all the Fe/HAP samples prepared by flash ionic exchange (a). The diffraction patterns of hydroxyapatite $(\mathbf{b})$, and iron oxide phases $(\mathbf{c})$ : $\mathrm{Fe}(\mathrm{OH})_{3}$, bernalite, JCPDS 00-046-1436, blue; $\mathrm{Fe}_{3} \mathrm{O}_{4}$, magnetite, JCPDS 00-019-0629, red; $\mathrm{\gamma}-\mathrm{FeO}(\mathrm{OH})$, lepidocrocite, JCPDS 00-044-1415, green; $\mathrm{Fe}_{2} \mathrm{O}_{3}$, hematite, JCPDS 00-033-0664, grey) are reported as reference. 
A further insight on the nature of iron phase can be gained from surface acid site titration by ammonia probe, being Fe species recognized Lewis acid centers. The bare HAP surface possessed a modest number of acid sites $\left(140.5 \mu \mathrm{mol} \cdot \mathrm{g}^{-1}\right.$, Table 1$)$, which gradually increased with Fe-loading up to a value of $262.4 \mu \mathrm{mol} \cdot \mathrm{g}^{-1}$ for the sample with the highest Fe-concentration (Figure S2). This suggests that further additions of Fe to HAP surface caused a steady slight increase in the dispersed iron species.

\subsection{Catalytic Results}

The catalytic performances of $\mathrm{Fe} / \mathrm{HAP}$ samples were evaluated in three reactions of importance for the abatement of air pollutants: $\mathrm{NH}_{3}-\mathrm{SCR}, \mathrm{NH}_{3}-\mathrm{SCO}$ and $\mathrm{N}_{2} \mathrm{O}$-decomposition. Each reaction has, individually, its worth, but more importantly the three catalytic reactions can be chained together in a cascade configuration with the aim to attain the goal of zero-emission combustion processes. Indeed, to achieve the desired complete conversion of $\mathrm{NO}_{x}$ vented from combustion plants, an excess amount of ammonia could be necessary in the $\mathrm{NH}_{3}-\mathrm{SCR}$ post-combustion unit. At the outlet of SCR reactor, unreacted ammonia must not be vented in the atmosphere, therefore, a catalytic process is required to abate the unreacted slipped ammonia. The addition of a selective oxidation (SCO) catalyst in cascade could help in solving the problem of ammonia slipping [34,35]. However, in some cases, and specifically at high temperatures, $\mathrm{N}_{2} \mathrm{O}$ is formed as main undesired by-product in the $\mathrm{NH}_{3}$-SCR and SCO processes. $\mathrm{N}_{2} \mathrm{O}$ can be, then, catalytically decomposed to harmless $\mathrm{N}_{2}$ and $\mathrm{O}_{2}$ in a third reaction step put in sequence.

In this work, as a preliminary point, the three reactions have been separately studied under typical experimental conditions used in conventionally in the literature to test the performances of Fe/HAP catalysts and individuate the best candidate for a cascade process.

\subsubsection{Selective Catalytic Reduction of $\mathrm{NO}_{\text {by }} \mathrm{NH}_{3}\left(\mathrm{NH}_{3}-\mathrm{SCR}\right)$}

In the standard $\mathrm{NH}_{3}-\mathrm{SCR}, \mathrm{NO}$ is reduced by $\mathrm{NH}_{3}$ with formation of $\mathrm{N}_{2}$ in the 1:1 stoichiometric ratio, according to the following reaction (Equation (1)):

$$
4 \mathrm{NO}+4 \mathrm{NH}_{3}+\mathrm{O}_{2} \rightarrow 4 \mathrm{~N}_{2}+6 \mathrm{H}_{2} \mathrm{O}
$$

As part of a complete selective process, $\mathrm{NH}_{3}$ is also oxidized to $\mathrm{N}_{2}$. From a kinetic point of view, reaction (1) is in competition with the unselective $\mathrm{NH}_{3}$ oxidation by $\mathrm{O}_{2}$, that produces $\mathrm{NO}$ and $\mathrm{N}_{2} \mathrm{O}$ (Equations (2) and (3)):

$$
\begin{gathered}
4 \mathrm{NH}_{3}+5 \mathrm{O}_{2} \rightarrow 4 \mathrm{NO}+6 \mathrm{H}_{2} \mathrm{O} \\
2 \mathrm{NH}_{3}+2 \mathrm{O}_{2} \rightarrow \mathrm{N}_{2} \mathrm{O}+3 \mathrm{H}_{2} \mathrm{O}
\end{gathered}
$$

In addition, depending on the gaseous mixture composition, the reaction between $\mathrm{NH}_{3}$ and $\mathrm{NO}$ can proceed through unselective pathways (Equations (4) and (5)), as detailed below:

$$
\begin{gathered}
4 \mathrm{NO}+4 \mathrm{NH}_{3}+3 \mathrm{O}_{2} \rightarrow 4 \mathrm{~N}_{2} \mathrm{O}+6 \mathrm{H}_{2} \mathrm{O} \\
4 \mathrm{NO}+4 \mathrm{NH}_{3}+3 \mathrm{O}_{2} \rightarrow 4 \mathrm{~N}_{2} \mathrm{O}+6 \mathrm{H}_{2} \mathrm{O}
\end{gathered}
$$

The occurrence of these side-reactions depends on the catalyst, on the temperature and on the feed composition (oxygen concentration, humidity) [36]. In particular, the unselective oxidative pathways are favored at high temperatures $\left(>350{ }^{\circ} \mathrm{C}\right)$. Both activity and selectivity must be met on a high performance SCR catalyst. The SCR activity over the studied Fe/HAP catalysts was investigated in the $120-500{ }^{\circ} \mathrm{C}$ temperature interval, by continuously feeding $500 \mathrm{ppm}$ of $\mathrm{NO}, 500 \mathrm{ppm}$ of $\mathrm{NH}_{3}$, $10,000 \mathrm{ppm}$ of $\mathrm{O}_{2}$ to the reactor at Gas Hourly Space Velocity (GHSV) of $30,000 \mathrm{~h}^{-1}$. 
Figure 2 and Figure S3a report the curves of $\mathrm{NO}_{x}\left(\mathrm{NO}+\mathrm{NO}_{2}\right)$ and of $\mathrm{NH}_{3}$ conversion and selectivity to $\mathrm{N}_{2}$ and $\mathrm{N}_{2} \mathrm{O}$ as a function of temperature for all Fe/HAP and bare HAP, respectively. They have been obtained from the experimental profiles of the $\mathrm{NO}, \mathrm{NO}_{2}, \mathrm{NH}_{3}, \mathrm{~N}_{2}$ and $\mathrm{N}_{2} \mathrm{O}$ outlet concentrations at steady state at the tested temperatures (Figure S4). Only low activity was observed over bare hydroxyapatite with $\mathrm{NO}_{x}$ conversion reaching a maximum of $20 \%$ between 300 and $400{ }^{\circ} \mathrm{C}$ (Figure S3a).

a) $\mathrm{Fe} 2 / \mathrm{HAP}$

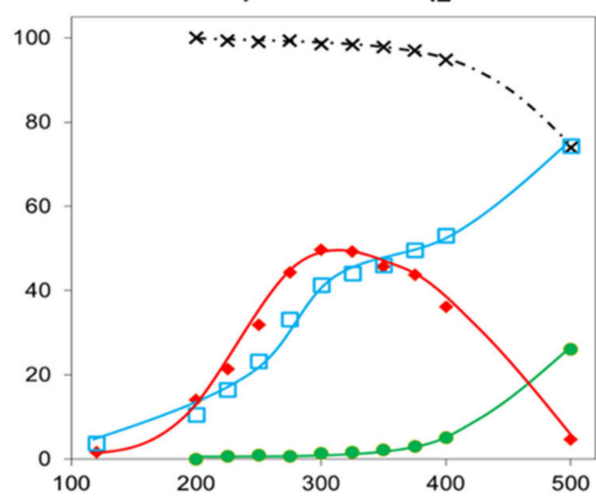

c) $\mathrm{Fe} 5 / \mathrm{HAP}$

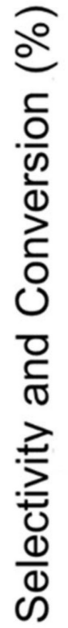

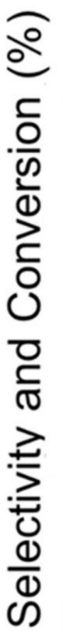

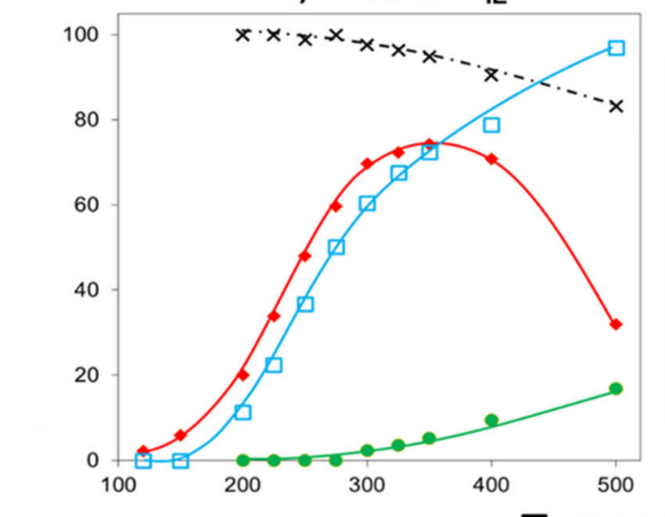

b) $\mathrm{Fe} 3 / \mathrm{HAP}_{\mathrm{IE}}$

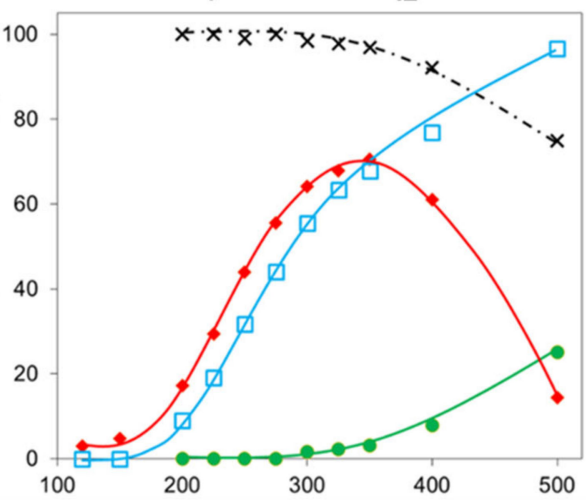

d) $\mathrm{Fe} 7 / \mathrm{HAP} \mathrm{PE}_{\mathrm{IE}}$
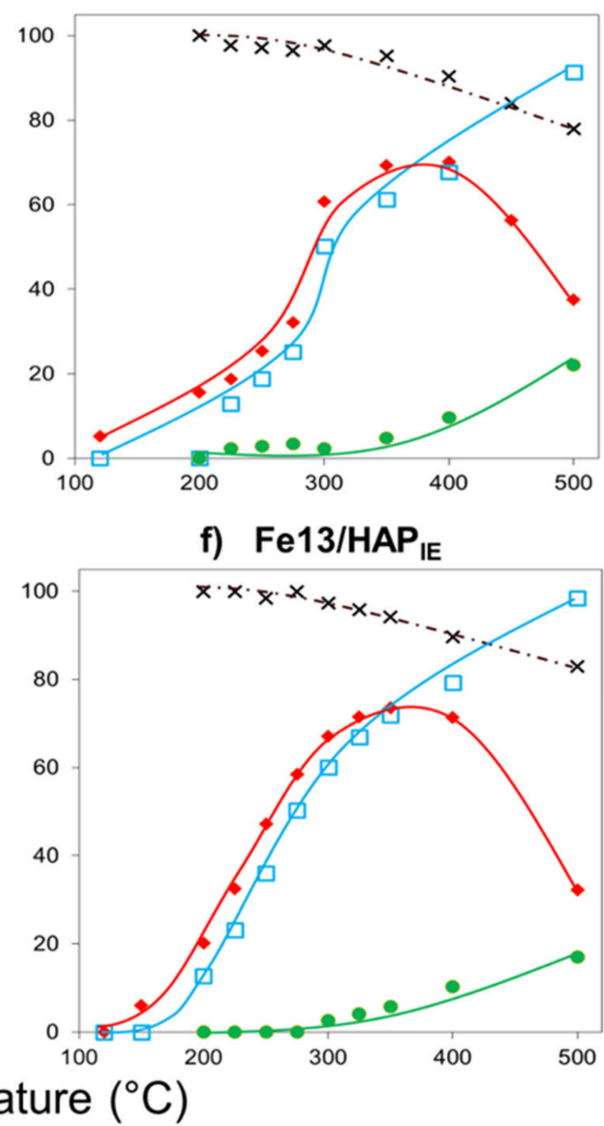

Figure 2. $\mathrm{NH}_{3}-\mathrm{SCR}$ catalytic activity results on $\mathrm{Fe} / \mathrm{HAP}$ samples $(\mathbf{a}-\mathbf{f})$ : profiles of conversion of the fed species $\left(\mathrm{NH}_{3}\right.$, light blue and $\mathrm{NO}$, red) and of selectivity of formed species $\left(\mathrm{N}_{2}\right.$, black and $\mathrm{N}_{2} \mathrm{O}$, green) as a function of temperature. Reaction conditions: $\left[\mathrm{NH}_{3}\right]=[\mathrm{NO}]=500 \mathrm{ppm},\left[\mathrm{O}_{2}\right]=10,000 \mathrm{ppm}$; GHSV $=30,000 \mathrm{~h}^{-1}$. 
The addition of iron, even at concentration as low as $2 \mathrm{wt} . \%$, imparted a sensitive enhancement of the catalytic activity with achievement of maximum of around $50 \%$ of $\mathrm{NO}_{x}$ conversion at $350{ }^{\circ} \mathrm{C}$ (Figure 2a). For higher Fe-concentrations (3-13 wt.\%), fine catalytic performances were observed over all the samples with a maximum $\mathrm{NO}_{x}$ conversion of about $60-75 \%$ at $350{ }^{\circ} \mathrm{C}$, without a clear trend of activity with iron loading. In all cases, $\mathrm{NH}_{3}$ and $\mathrm{NO}_{x}$ conversion curves experienced a monotonic increase, proceeding almost in parallel to each other upon temperature raising from 120 to $300{ }^{\circ} \mathrm{C}$. Consequently, the standard SCR reaction can be assumed to preferentially occur in this temperature window. In the higher temperature interval $\left(300-400{ }^{\circ} \mathrm{C}\right), \mathrm{NO}_{x}$ conversion values remained constant around a maximum, while above $400{ }^{\circ} \mathrm{C} \mathrm{NO}_{x}$ conversion dropped, whereas $\mathrm{NH}_{3}$ conversion kept increasing up to $100 \%$ at $500{ }^{\circ} \mathrm{C}$. This behavior was consistent with the occurrence of the unselective ammonia oxidation to $\mathrm{N}_{2} \mathrm{O}$ and $\mathrm{NO}$, as confirmed by the curve of selectivity to $\mathrm{N}_{2} \mathrm{O}$, which increased starting from $400{ }^{\circ} \mathrm{C}$, attaining a maximum of $20 \%$. Likely, formation of $\mathrm{N}_{2} \mathrm{O}$ at temperatures above $400{ }^{\circ} \mathrm{C}$ is caused also by ammonium nitrate decomposition. Selectivity to $\mathrm{N}_{2}$ exceeded $90 \%$ over all the catalysts in the temperature interval $150-400{ }^{\circ} \mathrm{C}$ and decreased down to ca. $80 \%$ at temperatures higher than $400^{\circ} \mathrm{C}$.

\subsubsection{Selective Catalytic Oxidation of $\mathrm{NH}_{3}\left(\mathrm{NH}_{3}-\mathrm{SCO}\right)$}

Over a suitable catalyst and under certain conditions (e.g., low temperature), $\mathrm{NH}_{3}$ could be selectively oxidized to $\mathrm{N}_{2}$ by oxygen, according to the following reaction (Equation (6)):

$$
4 \mathrm{NH}_{3}+3 \mathrm{O}_{2} \rightarrow 2 \mathrm{~N}_{2}+6 \mathrm{H}_{2} \mathrm{O}
$$

Also in this case, the process selectivity can be affected by the $\mathrm{NO}$ and $\mathrm{N}_{2} \mathrm{O}$ formation from parallel oxidation reactions (Equations (2)-(5)).

The catalytic performance of the Fe/HAP catalysts and bare HAP has been investigated under the conditions of $500 \mathrm{ppm} \mathrm{NH}_{3}, 10,000 \mathrm{ppm} \mathrm{O}_{2}$ at GHSV of 30,000 $\mathrm{h}^{-1}$.

As reported in Figure $\mathrm{S} 3 \mathrm{~b}, \mathrm{NH}_{3}$ conversion over bare HAP was lower than $5 \%$ below $375{ }^{\circ} \mathrm{C}$. Over this temperature, $\mathrm{NH}_{3}$ started to be oxidized and conversion increased up to ca. $45 \%$ at $500{ }^{\circ} \mathrm{C}$. Selectivity to $\mathrm{N}_{2}$ was low $(<40 \%)$ over the whole temperature interval.

The HAP functionalization with iron produced effective catalysts able to completely convert ammonia below $500^{\circ} \mathrm{C}$. Actually, as shown in the $\mathrm{NH}_{3}$ conversion profiles of Figure 3 a, $\mathrm{NH}_{3}$ conversion started at $350{ }^{\circ} \mathrm{C}$ and regularly increased until reaching $100 \%$ at $500{ }^{\circ} \mathrm{C}$. No remarkable differences among catalyst activities emerged with iron loading and $\mathrm{NH}_{3}$ conversion profiles vs. temperature almost overlapped.

a)

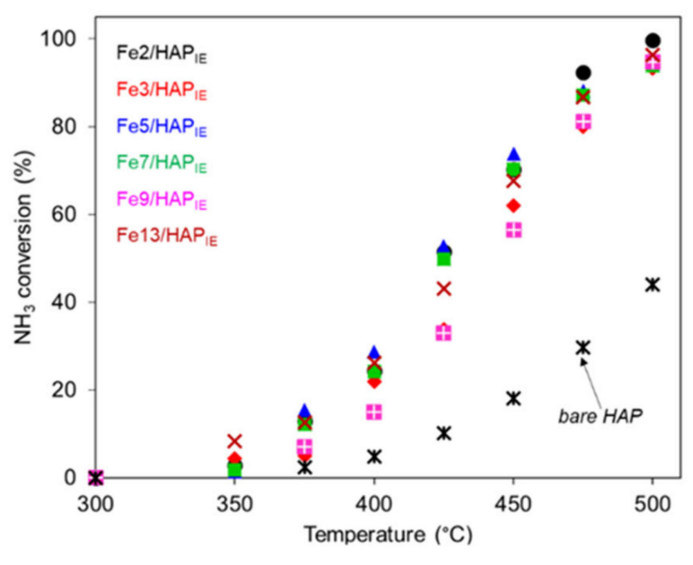

b)

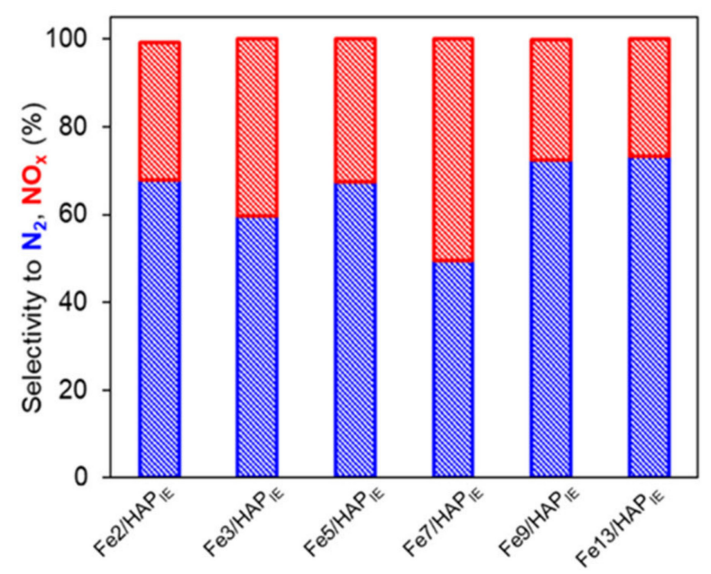

Figure 3. $\mathrm{NH}_{3}$-SCO catalytic activity results on Fe/HAP samples: (a) profiles of $\mathrm{NH}_{3}$ conversion as a function of temperature. (b) Selectivity to $\mathrm{N}_{2}$ (blue bars) and to $\mathrm{NO}_{x}$ (red bars) at $50 \%$ of $\mathrm{NH}_{3}$ conversion. Reaction conditions: $\left[\mathrm{NH}_{3}\right]=500 \mathrm{ppm},\left[\mathrm{O}_{2}\right]=10,000 \mathrm{ppm} ; \mathrm{GHSV}=30,000 \mathrm{~h}^{-1}$. 
Concerning selectivity to $\mathrm{N}_{2}$ (Figure $3 \mathrm{~b}$ ), although the addition of iron improved the reaction selectivity in comparison with $\mathrm{HAP}$, the evolution of $\mathrm{N}_{2} \mathrm{O}$ and $\mathrm{NO}_{x}$ formed from overoxidation side reactions, limited the complete selectivity of the $\mathrm{SCO}$ process, leading to relatively low values of $\mathrm{N}_{2}$, which did not exceed $70 \%$ over all Fe/HAP catalysts.

\subsection{3. $\mathrm{N}_{2} \mathrm{O}$ Decomposition}

As known, $\mathrm{N}_{2} \mathrm{O}$ is an extremely stable species that can be decomposed to $\mathrm{N}_{2}$ and $\mathrm{O}_{2}$ at very high temperature $\left(>800^{\circ} \mathrm{C}\right)$ following the simple reaction (Equation $\left.(7)\right)$ :

$$
2 \mathrm{~N}_{2} \mathrm{O} \rightarrow 2 \mathrm{~N}_{2}+\mathrm{O}_{2}
$$

When the reaction is performed over a suitable catalyst, it can proceed at relatively lower temperature.

$\mathrm{N}_{2} \mathrm{O}$ decomposition tests were carried out on all the Fe/HAP samples using low initial $\mathrm{N}_{2} \mathrm{O}$ concentration (ca. $150 \mathrm{ppm}$ ) in highly oxidant environment (ca. $6000 \mathrm{ppm}$ ) at GHSV $=30,000 \mathrm{~h}^{-1}$.

Figure 4 reports some catalytic activity results in terms of $\mathrm{N}_{2} \mathrm{O}$ conversion at different selected temperatures $\left(400,500\right.$ and $750{ }^{\circ} \mathrm{C}$ ). As a general trend, all the $\mathrm{Fe} / \mathrm{HAP}$ samples were active in the $\mathrm{N}_{2} \mathrm{O}$ decomposition, up to $80-100 \% \mathrm{~N}_{2} \mathrm{O}$ conversion achieved at $750{ }^{\circ} \mathrm{C}$. In particular, the presence of just $2 \mathrm{wt} . \%$ of Fe on HAP (Fe2/HAP $\mathrm{IE}$ ) conferred an increase of activity in comparison with the almost inactive HAP, which gave rise ca. $35 \%$ of $\mathrm{N}_{2} \mathrm{O}$ conversion at $750{ }^{\circ} \mathrm{C}$ (Figure S3c). In any case, the most interesting activities on the $\mathrm{Fe} / \mathrm{HAP}$ samples were observed at reaction temperatures higher than $500^{\circ} \mathrm{C}$. Low values of $\mathrm{N}_{2} \mathrm{O}$ conversion (up to a maximum of ca. $25 \%$ ) were detected at temperatures lower than $500{ }^{\circ} \mathrm{C}$, independently from Fe loading (Figure 4). At higher temperatures, the catalytic activity was found to increase with the Fe loading; the presence of high Fe-amount on HAP (ca. 9-13 wt.\%) guaranteed almost total $\mathrm{N}_{2} \mathrm{O}$ conversion at $750{ }^{\circ} \mathrm{C}$. In addition, Fe loading influenced also the operating temperature window of Fe/HAP catalysts, since catalysts with higher Fe content (9-13 wt.\%) converted $\mathrm{N}_{2} \mathrm{O}$ in a lower temperature interval than those at lower Fe content (2-7 wt.\%).

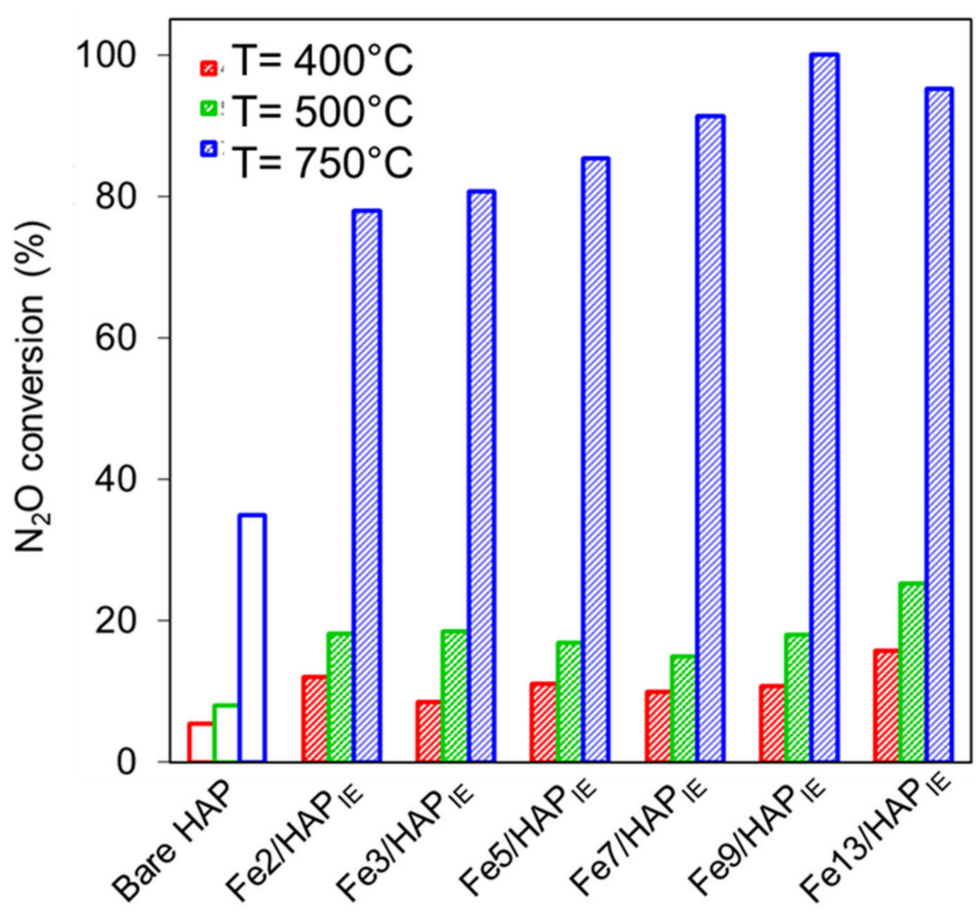

Figure 4. $\mathrm{N}_{2} \mathrm{O}$ decomposition catalytic activity results on Fe/HAP samples: $\mathrm{N}_{2} \mathrm{O}$ conversion at different temperatures $\left(400,500,750{ }^{\circ} \mathrm{C}\right)$. Reaction conditions: $\left[\mathrm{N}_{2} \mathrm{O}\right]=150 \mathrm{ppm},\left[\mathrm{O}_{2}\right]=6000 \mathrm{ppm}$; $\mathrm{GHSV}=30,000 \mathrm{~h}^{-1}$. 


\subsection{Catalyst Characterization}

A critical rationalizing of catalytic results cannot prescind from a targeted investigation on the nuclearity (e.g., isolated centers, dimers, oligomers, clusters, etc.) and nature of the iron phase onto HAP.

According to current knowledge [37,38], iron can be deposited on hydroxyapatite in the form of isolated paramagnetic $\mathrm{Fe}^{3+}$ ions even at iron loadings as high as $20 \mathrm{wt} . \%$. However, the underlying mechanisms for iron uptake from HAP are widely debated. Indeed, whilst there is overall agreement to consider a pure and stoichiometric exchange process between $\mathrm{Ca}^{2+}$ and $\mathrm{Fe}^{3+}$ implausible for charge imbalance reasons, on the other hand the identification of iron species formed after deposition still remains a controversial issue. In particular, Li et al. [37] hypothesized that the exchange between $\mathrm{Ca}^{2+}$ and $\mathrm{Fe}^{3+}$ was accompanied by the formation of vacancies on the calcium positions of the HAP lattice for compensating charge imbalance. On the basis of in situ FT-IR measurements, Kandori et al. [39] envisaged that Fe(III) would be incorporated into the HAP framework as hydroxyl ions-bivalent $\mathrm{Fe}(\mathrm{OH})^{2+}$ or monovalent $\mathrm{Fe}(\mathrm{OH})_{2}{ }^{+}$ions-keeping the charge balance. A similar view has been proposed by Kachani et al. [38]: at $\mathrm{pH}=2.3 \mathrm{Fe}^{3+}$ species would replace calcium ions as $\mathrm{Fe}(\mathrm{OH})\left(\mathrm{H}_{2} \mathrm{O}\right)_{5}{ }^{2+}$ species. Subsequent calcination of the catalysts resulted in the formation of isolated paramagnetic $\mathrm{Fe}^{3+}$ entities accompanied, as shown by InfraRed spectroscopy, by the removal of protons of the $\mathrm{OH}$ hydroxyls hosted by the apatite tunnels. These $\mathrm{Fe}^{3+}$ ions are allocated at the catalyst surface or in its proximity (as suggested by X-ray Photoelectron Spectroscopy, XPS) and occupy two types of sites, which were identified as distorted octahedra or sites with lower coordination.

In order to investigate the nature of iron species in the studied Fe/HAP samples, UV-Diffuse Reflectance (UV-DR) spectra were collected at room temperature in the 200-1200 nm range; they are reported in Figure 5 (left) with specific focus on the 200-800 nm region and compared with that of bare HAP (dotted black line). All the Fe/HAP spectra were characterized by typical absorption bands of iron species, ascribable to ligand-to metal charge transfer (CT) excitations from the $\mathrm{O}(2 \mathrm{p})$ nonbonding valence bands to $\mathrm{Fe}(3 \mathrm{~d})$ ligand field orbitals $\left(\mathrm{O}^{2-} \rightarrow \mathrm{Fe}^{3+}\right)$ and d-d (ligand field) transitions. However, the overlapping of different absorption signals required deconvolutions in sub-bands with the final aim to discriminate each contribution (Figure 5, right, for the sample Fe5/HAP $\mathrm{IE}_{\mathrm{IE}}$ and Figure S5 for all the Fe/HAP samples).

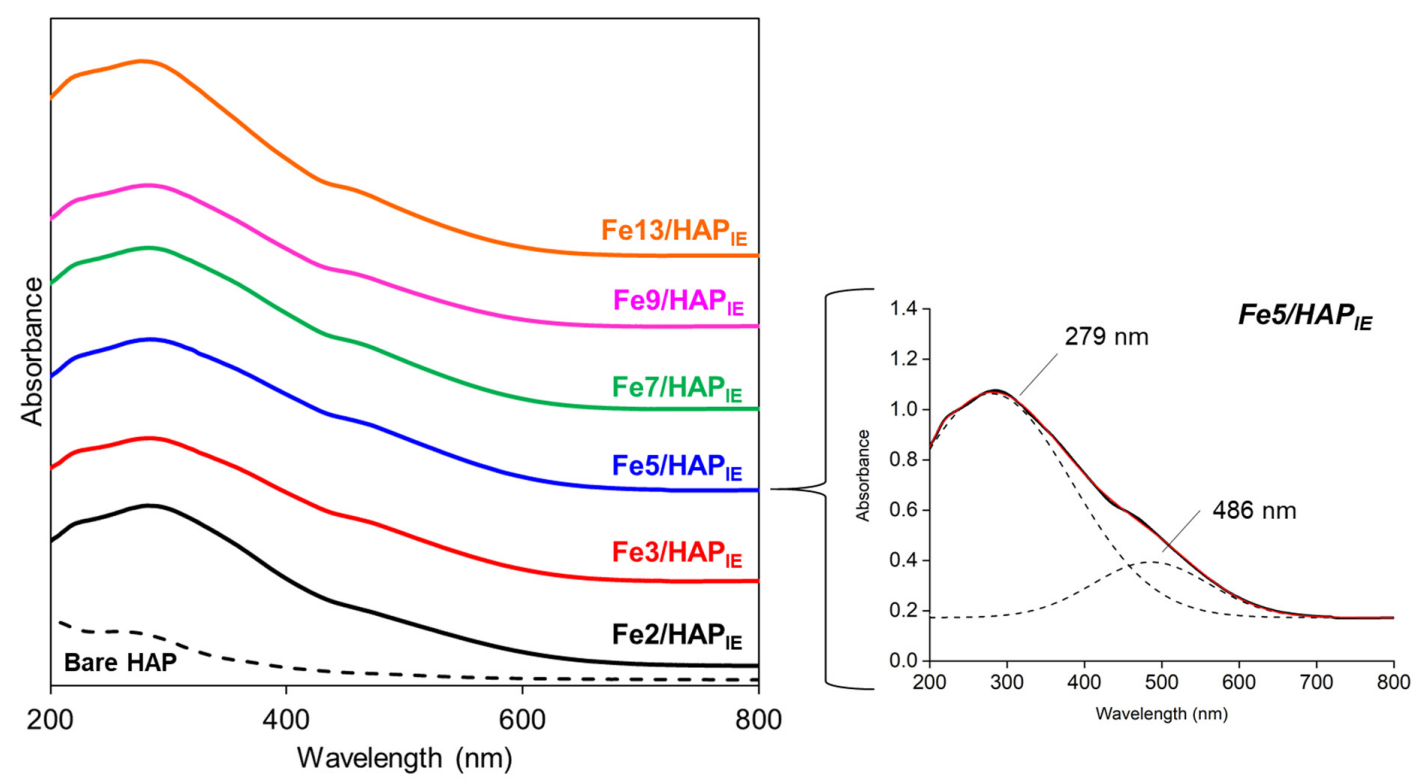

Figure 5. UV-vis DR spectra of Fe/HAP samples and bare HAP (left); deconvoluted spectrum of Fe5/HAP IE (right): calculated curve, red line, and decomposed curves, dotted black line with the related peak centers), chosen as an example. 
In all cases, spectra decomposition returned several features: an intense band in the 200-300 nm region caused by $\mathrm{CT}$ transitions, corresponding to the presence of isolated $\mathrm{Fe}^{3+}$ species, and a second broader band, in the 460-550 nm interval, typical of $\mathrm{d}-\mathrm{d}$ transitions from ground state to excited ligand field states $\left({ }^{6} \mathrm{~A}_{1} \rightarrow{ }^{4} \mathrm{~T}_{1}\right.$ or ${ }^{4} \mathrm{~T}_{2}$ or $\left.{ }^{4} \mathrm{E}\right)$. These latter are spin forbidden and generally characterized by low intensity. However, in the obtained spectra they showed a modest intensity, which demonstrated the presence of iron oxide aggregates when their neighboring iron centers possessing magnetic coupling, as reported in [40]. In addition, a further band at ca. $200 \mathrm{~nm}$ was observed in all the Fe/HAP spectra, comprised that of bare HAP (Figure 5, dotted black line): it was assigned to $\mathrm{O}^{2-} \rightarrow \mathrm{Ca}^{2+}$ charge transfer transition of the two non-equivalent $\mathrm{Ca}^{2+}$ sites present in the HAP lattice.

To gain a deeper insight on Fe-coordination at the HAP surface, Mössbauer spectra were collected at room temperature (Figure S6) and at $-260{ }^{\circ} \mathrm{C}$ (Figure S7) and fitted to compute the hyperfine parameters (Tables S2 and S3). Figure 6 reports the spectra obtained in the case of two Fe/HAP samples, presenting the lowest and highest Fe-loading among the prepared samples, $\left(\mathrm{Fe} 2 / \mathrm{HAP}_{\mathrm{IE}}\right.$, Figure $6 \mathrm{a}$ and Fe13/HAP ${ }_{\text {IE }}$, Figure $\left.6 b\right)$.

\section{a) $\mathrm{Fe} 2 / \mathrm{HAP} \mathrm{PE}_{\mathrm{IE}}$}

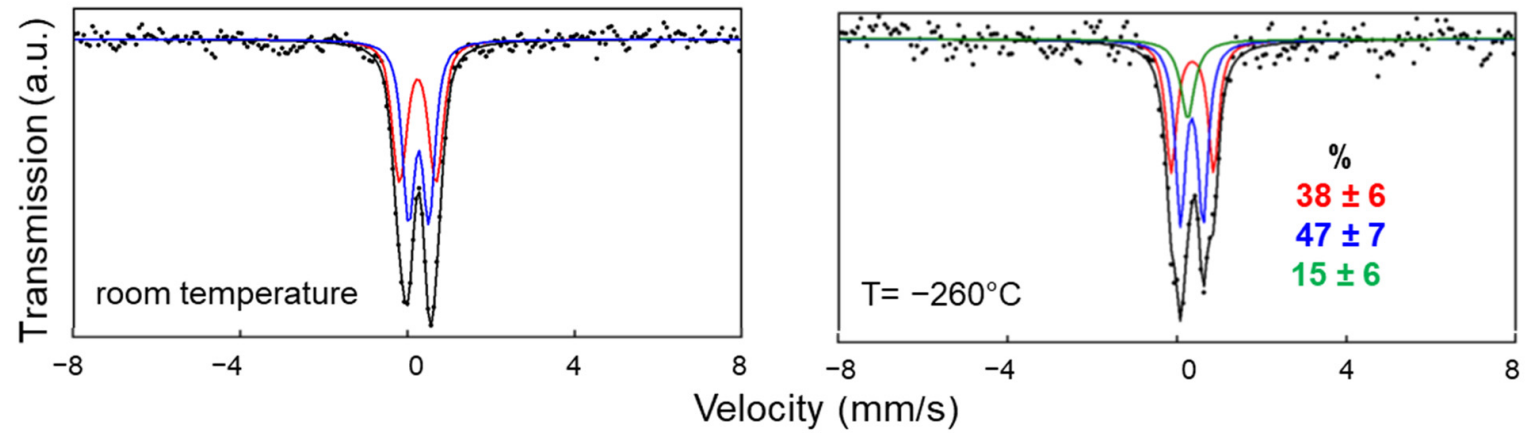

b) $\mathrm{Fe} 13 / \mathrm{HAP}_{\mathrm{IE}}$

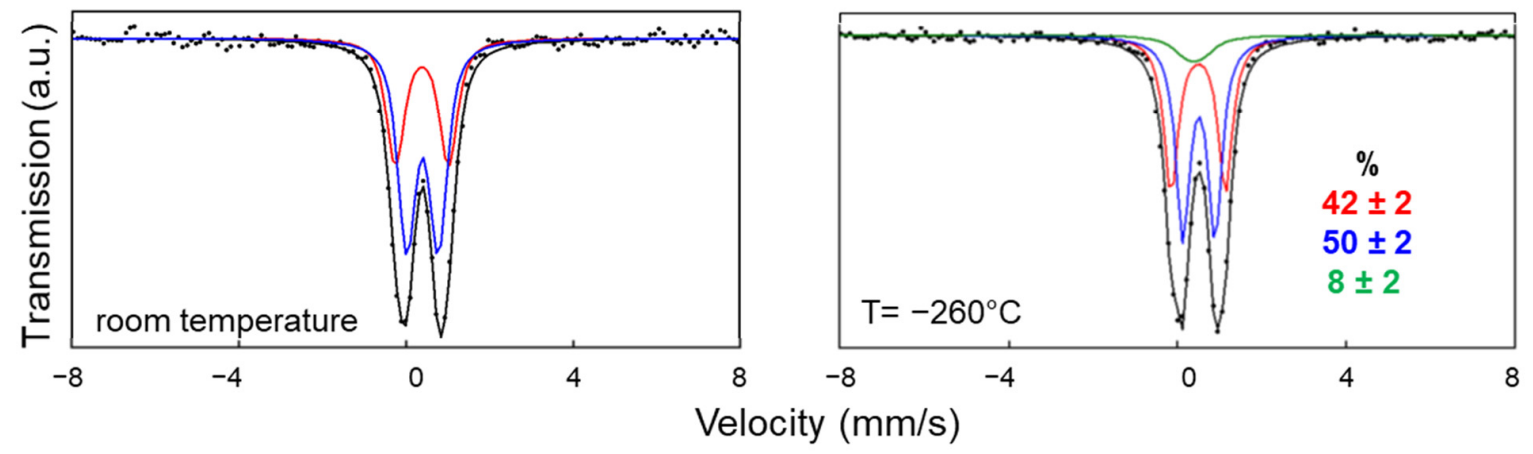

Figure 6. Mössbauer spectra of two Fe/HAP samples, presenting the lowest and the highest Fe-loading among Fe-loaded samples (Fe2/HAP $\mathrm{IE}_{\mathrm{IE}}(\mathbf{a})$, and $\mathrm{Fe} 13 / \mathrm{HAP}_{\mathrm{IE}},(\mathbf{b})$, respectively), chosen as representative sample, collected at room temperature (left) and at $-260{ }^{\circ} \mathrm{C}$ (right). Percentage values indicate the normalized population of $\mathrm{Fe}^{3+}$ centers.

In general, all the spectra obtained at room temperature (Figure S6) presented two main peaks, decomposed into two doublets (red and blue lines in Figure S6). However, these measurements did not provide for a unique identification of iron species because at this temperature the doublets could be alternatively associated to the presence of isolated paramagnetic $\mathrm{Fe}^{3+}$ species or to superparamagnetic iron oxide crystallites. In the former case, the fitting with doublets having distinct quadrupole splitting $\left(\Delta\right.$, Table S2) could be justified invoking an exchange occurring between isolated $\mathrm{Fe}^{3+}$ species and the two non-equivalent $\mathrm{Ca}^{2+}$ sites $(\mathrm{Ca}(\mathrm{I})$ and $\mathrm{Ca}(\mathrm{II}))$, or a surface complexation by two different HAP functional groups (carbonates, phosphates). On the other hand, in the case of iron oxides the lower values of quadrupole splitting ( $\Delta$, Table S2) could be ascribed to iron ions present inside the core of 
nanoparticles, while the higher values could be typical of iron ions located on the shell (with a highly asymmetric surrounding).

With the final purpose of fully discriminating between the two possible scenarios (isolated $\mathrm{Fe}^{3+}$ species vs. iron oxides), Mössbauer spectra at $-260{ }^{\circ} \mathrm{C}$ (Figure S7) were measured. Then, the best fitting and the hyperfine parameters of the spectra were evaluated (Table S3). The best fitting procedure assuring the lowest errors on calculation of the hyperfine parameters consisted in a combination of two doublets (red and blue lines, Figure S7) with an additional relaxing sextuplet (green line, Figure S7). At this low temperature, the presence of doublets could exclusively be associated to isolated $\mathrm{Fe}^{3+}$ species, since iron oxides must produce a sextuplet, at least partially blocked. On the other hand, the relaxing sextuplet has hyperfine parameters typical of iron oxides [41,42]. However, the dynamic magnetic behavior, due to the extremely small size of the clusters, hinders determination of presence or not of structural order. For this reason, we refer to them as $\mathrm{Fe}_{x} \mathrm{O}_{y}$. Based on previous considerations extensively reported in [26], the size of $\mathrm{Fe}_{x} \mathrm{O}_{y}$ species could be estimated to be around $2-4 \mathrm{~nm}$. A rough quantification of both isolated $\mathrm{Fe}^{3+}$ and $\mathrm{Fe}_{x} \mathrm{O}_{y}$ species could be done. Interestingly, the data shown in Table S3 suggested that the relative abundance of $\mathrm{Fe}_{x} \mathrm{O}_{y}$ nanoclusters is constant $(<15 \%)$, independently of the iron loading.

\section{Discussion}

An important point concerning the Fe/HAP catalysts is related to Fe sitting on HAP that represents a critical issue. The performed flash ion exchange procedure for depositing Fe-phase on HAP occurs at low $\mathrm{pH}$ value (ca. 3); under this condition, HAP gave partial dissolution, favoring the Ca-Fe exchange at the solid-liquid interface. In agreement with that, Mössbauer results indicated that isolated Fe-species could be located in the two inequivalent Ca-sites or dispersed by surface complexation. Actually, XPS data on a sample containing ca. 3 wt.\% of Fe showed a Ca/P ratio of about 1.11 and a $(\mathrm{Ca}+\mathrm{Fe}) / \mathrm{P}$ ratio of about 1.27 , lower than 1.33 , the $\mathrm{Ca} / \mathrm{P}$ value of bare HAP. This low decrease suggested us that Fe could be exchanged with $\mathrm{Ca}$ ions in a certain amount, while the remaining part should be adsorbed at the surface by complexation with the HAP functionalities $\left(\mathrm{OH}^{-}, \mathrm{PO}_{4}{ }^{3-}\right.$, etc.). Now, the discussion aims at correlating the catalytic performances of $\mathrm{Fe} / \mathrm{HAP}$ catalysts in the $\mathrm{NH}_{3}-\mathrm{SCR}$, $\mathrm{NH}_{3}-\mathrm{SCO}$ and $\mathrm{N}_{2} \mathrm{O}$-decomposition reactions with their structural and surface properties.

The functionalization of hydroxyapatite with iron species produced samples with enhanced acidity as shown by gas-solid phase titration with ammonia probe. The amount of adsorbed ammonia increased along with iron loading in the order: Fe2HAP $<$ Fe3HAP $<$ Fe5HAP $<$ Fe7HAP $<$ Fe9HAP $\cong$ Fe13/HAP (Table 1 and Figure S2). This is also in agreement with presence of Fe-isolated species at the HAP surface.

Actually, $\mathrm{Fe} / \mathrm{HAP}$ samples had good catalytic performances in the three studied reactions of selective transformation of $\mathrm{N}$-containing gaseous species $\left(\mathrm{NH}_{3}-\mathrm{SCR}, \mathrm{NH}_{3}-\mathrm{SCO}\right.$ and $\mathrm{N}_{2} \mathrm{O}$ decomposition).

All the Fe/HAP catalysts were active in $\mathrm{NO}$ reduction by $\mathrm{NH}_{3}\left(\mathrm{NH}_{3}\right.$-SCR) in a relatively low temperature range (between $225^{\circ} \mathrm{C}$ and $375{ }^{\circ} \mathrm{C}$ ). Even if the comparison of our results might be specious, it should be remarked that the catalytic performances of the catalysts are comparable or just slightly lower than those of some conventional Fe-zeolites (Fe-BEA, Fe-ZSM-5, Fe-MOR, Fe-FER, Fe-SSZ-13, Fe-SSZ-37) [43]. The best performing catalysts achieved up to $80 \% \mathrm{NO}$ conversion at $350{ }^{\circ} \mathrm{C}$; unfortunately, the decrease in $\mathrm{NO}$ conversion observed above $350{ }^{\circ} \mathrm{C}$ limited the catalyst selectivity.

This evidence is congruent with most of previous literature on iron-based SCR catalysts, and in particular on Fe-zeolite catalysts. On Fe-zeolites high de- $\mathrm{NO}_{x}$ activity at low temperature has been associated with mononuclear iron species involved as redox sites in the catalytic cycle [44], while dimeric, oligomeric and partially uncoordinated sites at the surface of $\mathrm{FeO}_{x}$ particles have been hypothesized to be active species responsible for SCR activity of Fe-zeolites at high temperatures [45,46]. Therefore, the co-presence of isolated and aggregated iron phases in our samples could justify the observed catalytic behavior. Indeed, the evidence that ammonia continued to be converted with increasing temperature until total conversion $(>99 \%)$ was achieved, suggests that the decrease in NO conversion 
observed above of $350{ }^{\circ} \mathrm{C}$ is probably due to the non-selective conversion of ammonia. From this point of view, the possibility to study separately three interconnected reactions (SCR, SCO and $\mathrm{N}_{2} \mathrm{O}$ decomposition) allowed to find proper correlations. Actually, ammonia oxidation in SCO tests started at $350{ }^{\circ} \mathrm{C}$, a temperature value that coincides with the maximum of $\mathrm{NO}$ conversion in SCR investigations. The good agreement between the activity in $\mathrm{NH}_{3}-\mathrm{SCR}$ and $\mathrm{NH}_{3}-\mathrm{SCO}$ tests confirmed the hypothesis that unselective catalytic oxidation of ammonia caused the decrease in NO conversion at high temperatures in the SCR tests.

It is known that on Fe-based catalysts high activity in $\mathrm{SCO}$ is associated with monomeric $\mathrm{Fe}^{3+}$ sites, which simultaneously serve as Lewis acid sites for the adsorption of ammonia and redox centers able to form active oxygen adsorbed species $\left(\mathrm{O}_{2}{ }^{\delta-}\right.$ with $\left.1 \leq \delta \leq 2\right)$. At high temperature clustered iron species become active in ammonia oxidation, however their high oxidation potential leads to unselective pathways [47]. Considering that $\mathrm{Fe} / \mathrm{HAP}$ catalysts started to be active only at high temperature ( $\mathrm{T}>350{ }^{\circ} \mathrm{C}$ ) and low selectivity to $\mathrm{N}_{2}$ was observed, we can guess that in this case only aggregated Fe-species are active in the oxidation of ammonia.

The low selectivity to $\mathrm{N}_{2}$ is accompanied with evolution of $\mathrm{N}_{2} \mathrm{O}$, which could derive either from ammonium nitrate decomposition or from combination between oxygen and adsorbed $\mathrm{NH}_{x}$ species, the latter mechanism being predominant at high temperatures [44].

The stability of formed $\mathrm{N}_{2} \mathrm{O}$ species under the conditions of SCR and SCO reactions is supported by catalytic $\mathrm{N}_{2} \mathrm{O}$ decomposition tests, which revealed that $\mathrm{N}_{2} \mathrm{O}$ started to be significantly dissociated into $\mathrm{N}_{2}$ and $\mathrm{O}_{2}$ only at temperatures higher than $500{ }^{\circ} \mathrm{C}$. An interesting correlation between the number of acid sites of the $\mathrm{Fe} / \mathrm{HAP}$ sample and $\mathrm{N}_{2} \mathrm{O}$ decomposition activity has been noted. Figure 7 reports the observed linear trend between $\mathrm{N}_{2} \mathrm{O}$ conversion (evaluated at $750{ }^{\circ} \mathrm{C}$ ) and $\mathrm{Fe} / \mathrm{HAP}$ acidity (expressed as $\mathrm{mmol}_{\mathrm{NH} 3, \mathrm{ads}} \cdot \mathrm{g}^{-1}$ ). The trend suggests that isolated $\mathrm{Fe}^{3+}$ centers could govern the activity of $\mathrm{N}_{2} \mathrm{O}$ decomposition. Actually, previous DFT studies demonstrated that isolated iron cations and oligonuclear iron species, which are also the main species revealed in Fe/HAP samples, are equally active in $\mathrm{N}_{2} \mathrm{O}$ dissociation [48,49]. In the former case an Eley-Rideal mechanism is likely active since two $\mathrm{N}_{2} \mathrm{O}$ molecules are adsorbed on isolated $[\mathrm{FeO}]^{+},\left[\mathrm{Fe}(\mathrm{OH})_{2}\right]^{+},\left[\mathrm{FeO}_{2}\right]^{+}, \mathrm{Fe}^{2+}, \mathrm{Fe}^{3+}$ cations and there decomposed in $\mathrm{N}_{2}$ and adsorbed $\mathrm{O}$ by $\mathrm{NN}-\mathrm{O}$ bond cleavage. The $\mathrm{O}$ atoms adsorbed on the same site are then recombined to form an $\mathrm{O}_{2}$ molecule. Differently, the cooperation between two vicinal iron sites in multinuclear aggregates favors the occurrence of the Langmuir-Hinshelwood mechanism, consisting in the adsorption and dissociation of $\mathrm{N}_{2} \mathrm{O}$ onto two distinct iron sites.

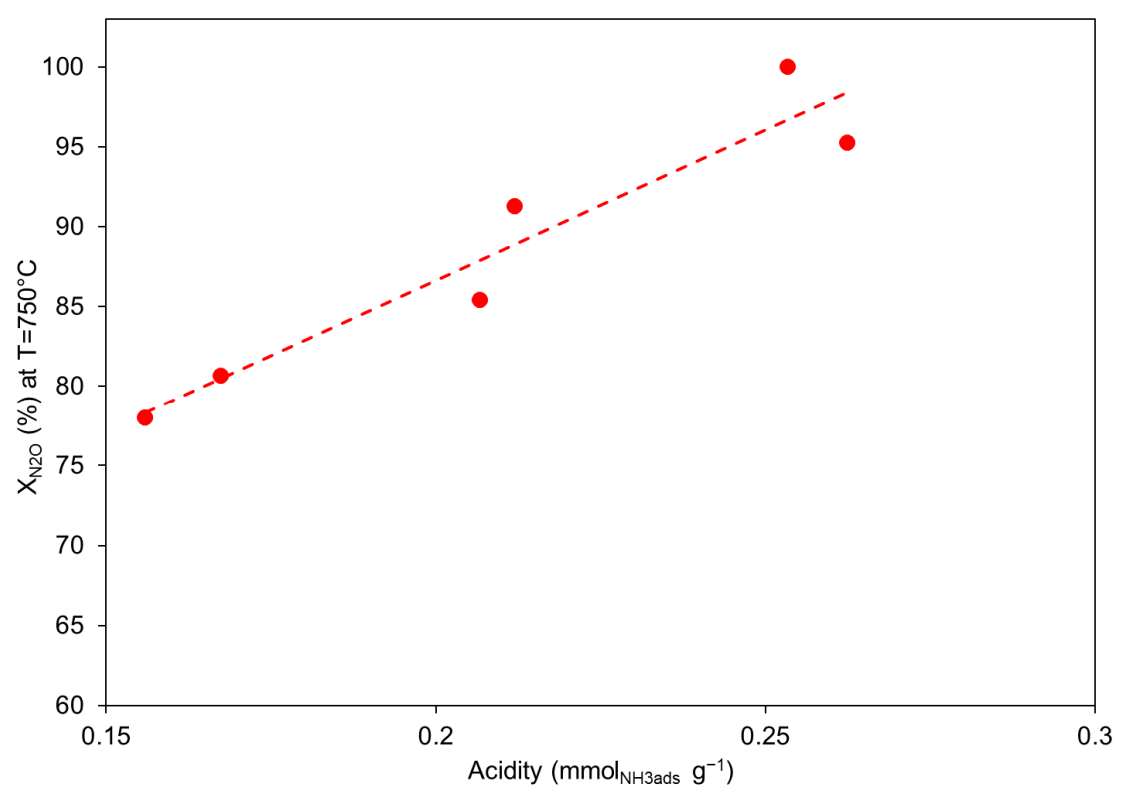

Figure 7. $\mathrm{N}_{2} \mathrm{O}$ conversion values (at fixed temperature, $750{ }^{\circ} \mathrm{C}$ ) as a function of acidity (expressed in $\mathrm{mmol}_{\mathrm{NH} 3, \mathrm{ads}} \cdot \mathrm{g}^{-1}$ ) of $\mathrm{Fe} / \mathrm{HAP}$ catalysts. 
At the end, Scheme 1 depicts the surfaces of Fe/HAP catalysts; the representation highlights the complex situation of the Fe/HAP samples with regard to the clear identification of the active metal species active in the studied reactions.

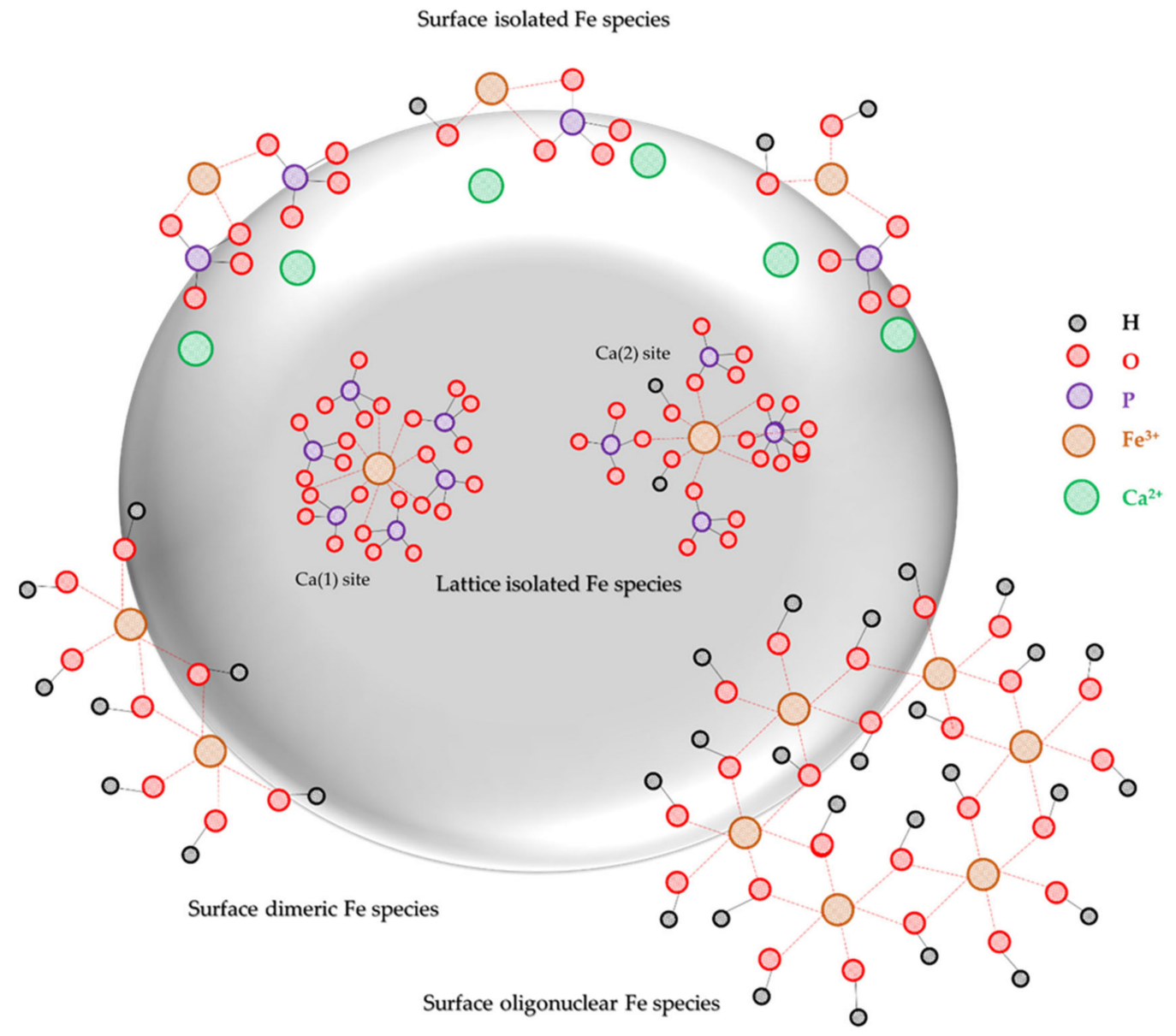

Scheme 1. Schematic view of iron species at the surface HAP grain.

\section{Materials and Methods}

\subsection{Materials and Catalyst Preparation}

Hydroxyapatite (HAP) used in this work was kindly supplied by Soda Ash \& Derivatives (Solvay, Brussels, Belgium): Its preparation procedure, composition and main properties were reported in Ref. [28].

Iron functionalized hydroxyapatite samples with different iron loading $(2<w t . \%<13)$ were prepared from iron(III)nitrate precursor $\left(\mathrm{Fe}\left(\mathrm{NO}_{3}\right)_{3} \cdot 9 \mathrm{H}_{2} \mathrm{O}\right.$ from Sigma Aldrich, St. Louis, $\mathrm{MO}$, USA) by a modified ion exchange (IE) procedure, called flash ionic exchange due to the short contact time of HAP in the Fe-solution [26,27].

For each preparation, $250 \mathrm{~mL}$ of iron(III) nitrate solution (with a concentration in the $0.005-0.06 \mathrm{M}$ range) were thermostated at $40{ }^{\circ} \mathrm{C}$. The $\mathrm{pH}$ was adjusted to ca. 3 by $\mathrm{HNO}_{3}$ addition to avoid the hydrolytic polymerisation of iron(III) occurring at higher $\mathrm{pH}$.

HAP powder (typically $6 \mathrm{~g}$, previously dried at $120^{\circ} \mathrm{C}$, overnight) was added to the iron(III) solution and the obtained suspension was vigorously stirred at $40^{\circ} \mathrm{C}$ for $15 \mathrm{~min}$. This short contact time assured to preserve both surface and structural properties of HAP, which is sensitive to amorphization or dissolution in an extremely acidic environment [29].

The obtained samples were filtered, thoroughly washed, dried at $120^{\circ} \mathrm{C}$ overnight and finally calcined at $500{ }^{\circ} \mathrm{C}$ for $1 \mathrm{~h}$ under static air at controlled rate $\left(1^{\circ} \mathrm{C} \cdot \mathrm{min}^{-1}\right)$. 
The collected samples were denoted as (FeX/HAP) $)_{\mathrm{IE}}$, where $\mathrm{X}$ is the Fe loading (in wt.\%). Fe loading for all the catalysts was double-checked by atomic absorption spectroscopy (PinAAcle 900T, S/N PTDS11062202, Perkin Elmer, Waltham, MA, USA) both on the solid after mineralization of a small amount $(c a .50 \mathrm{mg}$ ) of samples and on the filtration solutions. In any case, the percentage difference between two measurements was lower than $2 \%$.

\subsection{Characterization}

\subsection{1. $\mathrm{N}_{2}$ Adsorption-Desorption Isotherms at $-196^{\circ} \mathrm{C}$}

Specific surface area (S.A.) and porosity (pore volume, pore size and pore size distribution) were determined by $\mathrm{N}_{2}$ adsorption/desorption isotherms collected at $-196{ }^{\circ} \mathrm{C}$ using an automatic analyser of surface area (Sorptomatic 1990, Thermo Scientific Carlo Erba, Milano, Italy).

Prior to the analysis, fresh sample ( $c a .0 .20 \mathrm{~g}$ sieved to have particles in the range of 80-200 mesh) was outgassed at $350^{\circ} \mathrm{C}$ for $4 \mathrm{~h}$ under vacuum to remove water and other volatile organic compounds adsorbed on the surface. The specific surface area was calculated by means of the Brunauer-Emmet-Teller (BET) equation (2-parameters, $\mathrm{p} / \mathrm{p}^{\circ}$ range from 0.05 to 0.3 ). Pore volume and pore size distribution (PSD) were determined by Barrett-Joyner-Halenda (BJH) model equation from the desorption branch $\left(0.3<\mathrm{p} / \mathrm{p}^{0}<0.95\right)$ of the collected isotherms.

\subsubsection{X-ray Powder Diffraction (XRPD)}

The crystal structures and phase compositions of all the samples were determined by X-ray powder diffraction powder diffractometer consisting of a PW 1830 generator (Philips, Almelo, The Netherlands), monochromator in graphite, copper pipe ( $\mathrm{Cu} \alpha$ radiation at $40 \mathrm{kV} \cdot 40 \mathrm{~mA}$ ) in the range between $5^{\circ}-65^{\circ}(2 \theta)$, step of $0.033^{\circ} 2 \theta$, time for step of $50 \mathrm{~s}$ and total acquisition time of $1 \mathrm{~h} 23 \mathrm{~min}$. Before the analyses, powder samples were finely ground and spread on an aluminum flat-plate horizontal sample holder. Patterns were identified by comparison with the Joint Committee on Powder Diffraction Standards (JCPDS) files from International Center for Diffraction Data Powder Diffraction.

\subsection{3. $\mathrm{NH}_{3}$ Adsorption}

Acidity of bare HAP and Fe/HAP samples was determined by $\mathrm{NH}_{3}$ adsorption under flowing dynamic experiments. The dried sample (ca. $0.2 \mathrm{~g}, 45-60 \mathrm{mesh}$ ) was activated at $120^{\circ} \mathrm{C}$ under flowing air for 30 min in a quartz tubular reactor; then, the $\mathrm{NH}_{3} / \mathrm{N}_{2}$ mixture $\left(1.00 \%, \mathrm{NH}_{3}\right.$ concentration of ca. $500 \mathrm{ppm}$ ) flowed at $6 \mathrm{NL} \cdot \mathrm{h}^{-1}$ through the reactor and reached a gas cell (path length $2.4 \mathrm{~m}$ multiple reflection gas cell) in the beam of an Fourier Transform InfraRed spectrometer, FT-IR (equipped with a DTGS detector, Bio-Rad, Hercules, CA, USA). The $\mathrm{NH}_{3}$ line $\left(966 \mathrm{~cm}^{-1}\right)$ was monitored as a function of time. On all the samples, $\mathrm{NH}_{3}$ was completely adsorbed, as observed from the shape of the $\mathrm{NH}_{3}$-signal profile, which decreased and remained to zero for a given measured time. When saturation of the acid sites by $\mathrm{NH}_{3}$ was attained, the $\mathrm{NH}_{3}$ signal was restored at the same value of its starting concentration. From the evaluation of the time during which the $\mathrm{NH}_{3}$-signal has remained to zero, the amount of acid sites could be evaluated, according to Equation (8):

$$
\frac{\text { moles }_{\mathrm{NH}_{3(a d s)}}}{g_{\text {sample }}}=\frac{\left[\mathrm{NH}_{3}\right]_{\text {fed }} \cdot F \cdot t \cdot P}{R T \cdot m_{\text {sample }}}
$$

where $\left[\mathrm{NH}_{3}\right]_{\text {fed }}$ is the flowing $\mathrm{NH}_{3}$ concentration, in ppm; $F$ is the total flow rate of the $\mathrm{NH}_{3} / \mathrm{N}_{2}$ mixture, in $\mathrm{NL} \cdot \mathrm{h}^{-1}$; $t$ is the time during which $\mathrm{NH}_{3}$ was completely adsorbed, in min; $P$ is the pressure, in atm; and $m_{\text {sample }}$ is the sample mass, in $g$.

Assuming a 1:1 stoichiometry for the $\mathrm{NH}_{3}$ adsorption on the surface acid site, the amount of acid sites per sample mass (in $\mu \mathrm{mol} \cdot \mathrm{g}^{-1}$ ) was determined. Measurements were replicated and a percent relative uncertainty lower than $2 \%$ was obtained. 


\subsubsection{UV Diffuse Reflectance Spectroscopy (UV-DRS)}

Diffuse reflectance spectra (DRS) were collected through a double beam UV-vis-NIR scanning spectrophotometer (UV-3600 plus, Shimadzu, Kyoto, Japan) equipped with a diffuse reflectance accessory (integrating sphere from BIS-603). Powder samples were finely grinded, uniformly pressed in a circular disk (E.D., ca. $4 \mathrm{~cm}$ ) and included in the sample-holder. The latter was inserted in a quartz cuvette and put on a window of the integrating sphere for the reflectance measurements. Spectra were measured with ultrafine barium sulfate as reference. The measured reflectance profiles $(R \infty, \%)$ in the 200-1200 nm range were converted to absorbance (Abs) by Equation (9):

$$
\text { Abs }=\log (1 / \operatorname{Ro} / 100)
$$

The as-obtained UV-DR spectra (absorbance vs. wavelength, $\mathrm{nm}$ ) in the range $200-800 \mathrm{~nm}$ were decomposed using the software OriginPro8 (OriginLab Corporation, Northampton, MA, USA, 2018) with a combination of Gaussian functions.

\subsubsection{Mössbauer Spectroscopy}

Mössbauer spectra were obtained in transmission geometry using a 512-channel constant acceleration spectrometer (WissEl, Starnberg, Germany), provided with a source of ${ }^{57} \mathrm{Co}$ in $\mathrm{Rh}$ matrix of nominally $50 \mathrm{mCi}$. The ideal thickness of the sample was evaluated considering the weight percentages of the different elements of each catalyst (ca. $100 \mathrm{mg}$ of powder was used in a holder with diameter of ca. $1.8 \mathrm{~cm}$ ). The reference used for the velocity calibration was a $12-\mu \mathrm{m}$-thick $\alpha$-Fe foil. Spectra were collected at -260 and $25^{\circ} \mathrm{C}$. Measurements at low temperatures were performed working with a closed-cycle cryogenic system (Model DE-202, ARS, Macungie, PA, USA). Each spectrum was folded to minimize geometric effects; the experimental data were fitted using Recoil [50], a commercial program with constraints.

\subsubsection{Catalytic Tests}

Catalytic performances of all the Fe/HAP samples in $\mathrm{NH}_{3}-\mathrm{SCR}, \mathrm{NH}_{3}-\mathrm{SCO}$ and $\mathrm{N}_{2} \mathrm{O}$ decomposition were evaluated using a continuous reaction line equipped with a set of mass flow controllers (Bronkhorst, Hi-Tech Instruments, Nijverheidsstraat, Netherlands), a tubular vertical electric oven (Controller-Programmer type 818, Eurotherm, Guanzate, Como, Italy), a quartz tubular catalytic micro reactor (5 $\mathrm{mm}$ i.d.), and an online FT-IR spectrophotometer with a DTGS detector (Bio-Rad, Hercules, CA, USA) for qualitative and quantitative determination of the fed and vented gaseous species.

In a typical experiment, a fixed amount of catalyst sample (ca. $200 \mathrm{mg}$ ) was pressed, crushed, sieved to obtain particles in the range $45-60$ mesh $(0.35-0.25 \mathrm{~mm})$, and dried at $120^{\circ} \mathrm{C}$ overnight. Then, catalyst pretreatment was performed in situ under $\mathrm{O}_{2} / \mathrm{N}_{2}$ flow $(20 \% \mathrm{v} / \mathrm{v})$ at $120^{\circ} \mathrm{C}$ for $30 \mathrm{~min}$.

The catalytic activities were studied as a function of the temperature in the $120-500{ }^{\circ} \mathrm{C}$ interval for both $\mathrm{NH}_{3}-\mathrm{SCR}$ and $\mathrm{NH}_{3}-\mathrm{SCO}$, and $300-800{ }^{\circ} \mathrm{C}$ for $\mathrm{N}_{2} \mathrm{O}$ decomposition, keeping constant the concentration of fed gas mixture and using a total flow rate of $6 \mathrm{NL} \cdot \mathrm{h}^{-1}$ (GHSV of ca. $30.000 \mathrm{~h}^{-1}$ ). Each temperature was maintained for $60 \mathrm{~min}$ to guarantee the attainment of the steady-state reaction condition. The temperature was increased at step in aleatory way using a ramp of $10^{\circ} \mathrm{C} \cdot \mathrm{min}^{-1}$.

The fed gas mixtures were prepared by mixing $500 \mathrm{ppm}$ of $\mathrm{NH}_{3}, 500 \mathrm{ppm}$ of $\mathrm{NO}$ and 10,000 ppm of $\mathrm{O}_{2}$ for $\mathrm{NH}_{3}$-SCR tests; $500 \mathrm{ppm}$ of $\mathrm{NH}_{3}$ and 10,000 ppm of $\mathrm{O}_{2}$ for $\mathrm{NH}_{3}$-SCO tests; ca. 150 ppm of $\mathrm{N}_{2} \mathrm{O}$ and 6000 ppm of $\mathrm{O}_{2}$ for $\mathrm{N}_{2} \mathrm{O}$ decomposition tests. In all cases, nitrogen was used as inert gas.

The effluent gas mixtures from the reactor was monitored by an online FT-IR consisted of a multiple reflection gas cell—with $2.4 \mathrm{~m}$ path length; resolution, $2 \mathrm{~cm}^{-1}$; sensibility, 1.5, 92 scans per $180 \mathrm{~s}$-for quantifying the unconverted reagents and/or products.

The total absorbance of all the IR active gaseous species (Gram-Schmidt) vented by the reactor was continuously recorded as a function of time and the reaction temperature was changing. $\mathrm{NH}_{3}$, $\mathrm{NO}, \mathrm{N}_{2} \mathrm{O}$ and $\mathrm{NO}_{2}$ were quantified considering the peak height of a selected absorbance line and the 
measured calibration factors. Details on calculations for each reaction are reported in the Supplementary Material (Table S1).

\section{Conclusions}

The results reported in this work, where new Fe-based eco-friendly catalysts were tested in three environmental protection reactions, show that it is possible to overcome the use of more conventional ceramic-based catalysts (alumina, silica, zirconium, etc.) and approach the use of more environmentally friendly and eco-sustainable materials, such as hydroxyapatite. Suitably metal-functionalized, hydroxyapatite can give good catalytic performances in the $\mathrm{NO}_{x}, \mathrm{~N}_{2} \mathrm{O}$ and $\mathrm{NH}_{3}$ abatement reactions, which can be exploited for the abatement of gaseous pollutants among the worst of our environment.

Three environmental protection reactions studied ( $\mathrm{NH}_{3}-\mathrm{SCR}, \mathrm{NH}_{3}-\mathrm{SCO}$ and $\mathrm{N}_{2} \mathrm{O}$-decomposition) could also be performed in a single cascade process to achieve the desired zero emissions goal. For the cascade process, the most promising catalyst among those studied is at an average concentration of $\mathrm{Fe}$ (about 6-9 wt.\%), to guarantee a surface composed of isolated $\mathrm{Fe}^{3+}$ ions or oligonuclear species that ensure good activity with an equally good selectivity.

Much work still needs to be done to understand the performances of these new catalysts with dispersed iron on hydroxyapatite. In particular, the catalytic performances must be tested under real conditions, i.e., in the presence of water vapor, sulfur, alkali, etc. Part of this work is ongoing and the results will be presented shortly in the literature.

Supplementary Materials: The following are available online at http://www.mdpi.com/2073-4344/10/12/1415/s1, Figure S1: $\mathrm{N}_{2}$ adsorption/desorption isotherms at $-196^{\circ} \mathrm{C}$ of bare $\mathrm{HAP}$ calcined at $500^{\circ} \mathrm{C}$ (a) and of two $\mathrm{Fe} / \mathrm{HAP}$, presenting the lowest and the highest Fe-loading among Fe-loaded samples $\left(\mathrm{Fe} 2 / \mathrm{HAP} \mathrm{IE}_{\mathrm{IE}}, \mathrm{b}\right.$, and $\mathrm{Fe} 13 / \mathrm{HAP} \mathrm{IE}_{\mathrm{IE}}, \mathrm{c}$, respectively). Figure S2: Activity trend (in $\mu \mathrm{mol}_{\mathrm{NH} 3} / \mathrm{g}$ ) of Fe/HAP samples as a function of Fe-concentration (expressed in $\mathrm{mmol}_{\mathrm{Fe}} / \mathrm{g}$ ) with indication of HAP acidity (black marker). Figure S3: Catalytic activity results on bare HAP: (a) $\mathrm{NH}_{3}$-SCR: profiles of conversion of fed species $\left(\mathrm{NH}_{3}\right.$ and $\left.\mathrm{NO}_{x}\right)$ and formed species $\left(\mathrm{N}_{2}\right.$ and $\mathrm{N}_{2} \mathrm{O}$ ) as a function of temperature; (b) $\mathrm{NH}_{3}$-SCO: profiles of conversion of fed species $\left(\mathrm{NH}_{3}\right)$ and formed species $\left(\mathrm{N}_{2}\right.$ and $\mathrm{NO}_{x}$ ) as a function of temperature; (c) $\mathrm{N}_{2} \mathrm{O}$ decomposition: profile of $\mathrm{N}_{2} \mathrm{O}$ conversion as a function of temperature. Figure $\mathrm{S} 4: \mathrm{NH}_{3}$-SCR catalytic activity results on Fe/HAP samples: profiles of concentration of fed species $\left(\mathrm{NH}_{3}\right.$ and $\left.\mathrm{NO}\right)$ and formed species $\left(\mathrm{N}_{2}\right.$ and $\left.\mathrm{N}_{2} \mathrm{O}, \mathrm{NO}_{2}\right)$ as a function of temperature. Reaction conditions: $\left[\mathrm{NH}_{3}\right]=[\mathrm{NO}]=500 \mathrm{ppm},\left[\mathrm{O}_{2}\right]=10,000 \mathrm{ppm} ; \mathrm{GHSV}=30,000 \mathrm{~h}^{-1}$. Figure S5: UV-vis DR spectra (black curves) of Fe/HAP samples (a-e): total calculated curves (red lines) and decomposed curves (dotted black lines) with the related peak centers are also reported. Figure S6 Mössbauer spectra of Fe/HAP samples (a-d) collected at room temperature. Figure S7: Mössbauer spectra of Fe/HAP samples (a-d) collected at $-260^{\circ} \mathrm{C}$. Table S1: Symbols and calculations for computing catalytic parameters. Table S2: Mössbauer parameters of all the Fe/HAP samples at room temperature. Table S3: Mössbauer parameters of all the Fe/HAP samples collected at $-260^{\circ} \mathrm{C}$.

Author Contributions: Conceptualization and design of the work, S.C. and A.G.; writing, M.G.G., S.C. and S.G.M.; main investigation of catalyst properties, realization of catalytic tests and data curation, M.G.G.; catalyst preparation, Atomic Absorption Spectroscopy and XRPD analyses, and critical revision, S.C.; Mössbauer analyses and interpretation, S.G.M.; supervision, A.G. All authors have read and agreed to the submitted version of the manuscript.

Funding: This research received no external funding.

Acknowledgments: Solvay: Soda Ash and Derivatives (Bruxelles, Belgium) is gratefully acknowledged for supplying hydroxyapatite, in particular Thierry Deplanche, Capterall ${ }^{\circledR}$ Technology Manager. The use of instrumentation purchased through the SmartMatLab Project of Dipartimento di Chimica (Cariplo Foundation, project 2013-1776) is gratefully acknowledged and also Daniele Marinotto of Consiglio Nazionale delle Ricerche (CNR), Istituto di Scienze e Tecnologie Molecolari (ISTM). Iolanda Biraghi of Università degli Studi di Milano is acknowledged for her experimental support.

Conflicts of Interest: The authors declare no conflict of interest.

\section{References}

1. Liu, Y.; Zhao, J.; Lee, J.-M. Conventional and New Materials for Selective Catalytic Reduction (SCR) of $\mathrm{NO}_{\mathrm{x}}$. ChemCatChem 2018, 10, 1499-1511. [CrossRef]

2. Bosch, H.; Janssen, F. Catalytic Reduction of Nitrogen Oxides: A Review on the Fundamentals and Technology; Elsevier: Amsterdam, The Netherlands, 1988; Volume 7. 
3. Damma, D.; Ettireddy, P.; Reddy, B.; Smirniotis, P. A Review of Low Temperature $\mathrm{NH}_{3}-\mathrm{SCR}$ for Removal of $\mathrm{NO}_{\mathrm{x}}$. Catalysts 2019, 9, 349. [CrossRef]

4. Yan, Z.; Shan, W.; Shi, X.; He, G.; Lian, Z.; Yu, Y.; Shan, Y.; Liu, J.; He, H. The way to enhance the thermal stability of $\mathrm{V}_{2} \mathrm{O}_{5}$-based catalysts for $\mathrm{NH}_{3}$-SCR. Catal. Today 2019. [CrossRef]

5. Li, J.; Chang, H.; Ma, L.; Hao, J.; Yang, R.T. Low-temperature selective catalytic reduction of $\mathrm{NO}_{x}$ with $\mathrm{NH}_{3}$ over metal oxide and zeolite catalysts-A review. Catal. Today 2011, 175, 147-156. [CrossRef]

6. Ye, Q.; Wang, L.; Yang, R.T. Activity, propene poisoning resistance and hydrothermal stability of copper exchanged chabazite-like zeolite catalysts for SCR of NO with ammonia in comparison to Cu/ZSM-5. Appl. Catal. A Gen. 2012, 427-428, 24-34. [CrossRef]

7. Klimczak, M.; Kern, P.; Heinzelmann, T.; Lucas, M.; Claus, P. High-throughput study of the effects of inorganic additives and poisons on $\mathrm{NH}_{3}$-SCR catalysts-Part $\mathrm{I}: \mathrm{V}_{2} \mathrm{O}_{5}-\mathrm{WO}_{3} / \mathrm{TiO}_{2}$ catalysts. Appl. Catal. B Environ. 2010, 95, 39-47. [CrossRef]

8. Kern, P.; Klimczak, M.; Heinzelmann, T.; Lucas, M.; Claus, P. High-throughput study of the effects of inorganic additives and poisons on $\mathrm{NH}_{3}$-SCR catalysts. Part II: Fe-zeolite catalysts. Appl. Catal. B Environ. 2010, 95, 48-56. [CrossRef]

9. Lai, J.K.; Wachs, I.E. A Perspective on the Selective Catalytic Reduction (SCR) of NO with $\mathrm{NH}_{3}$ by Supported $\mathrm{V}_{2} \mathrm{O}_{5}-\mathrm{WO}_{3} / \mathrm{TiO}_{2}$ Catalysts. ACS Catal. 2018, 8, 6537-6551. [CrossRef]

10. Brandenberger, S.; Kröcher, O.; Tissler, A.; Althoff, R. The State of the Art in Selective Catalytic Reduction of $\mathrm{NO}_{\mathrm{x}}$ by ammonia Using Metal-Exchanged Zeolite Catalysts. Catal. Rev. 2008, 50, 492-531. [CrossRef]

11. Ibrahim, M.; Labaki, M.; Giraudon, J.-M.; Lamonier, J.-F. Hydroxyapatite, a multifunctional material for air, water and soil pollution control: A review. J. Hazard. Mater. 2020, 383, 121139. [CrossRef]

12. Campisi, S.; Evangelisti, C.; Postole, G.; Gervasini, A. Combination of interfacial reduction of hexavalent chromium and trivalent chromium immobilization on tin-functionalized hydroxyapatite materials. Appl. Surf. Sci. 2021, 539, 148227. [CrossRef]

13. Campisi, S.; Castellano, C.; Gervasini, A. Tailoring the structural and morphological properties of hydroxyapatite materials to enhance the capture efficiency towards copper(II) and lead(II) ions. New J. Chem. 2018, 42, 4520-4530. [CrossRef]

14. Agbeboh, N.I.; Oladele, I.O.; Daramola, O.O.; Adediran, A.A.; Olasukanmi, O.O.; Tanimola, M.O. Environmentally sustainable processes for the synthesis of hydroxyapatite. Heliyon 2020, 6, e03765. [CrossRef] [PubMed]

15. Zoubeir, L.; Adeline, S.; Laurent, C.S.; Yoann, C.; Truc, H.T.; Benoît, L.G.; Federico, A. The use of the Novosol process for the treatment of polluted marine sediment. J. Hazard. Mater. 2007, 148, 606-612. [CrossRef]

16. Pretto, M.; Costa, A.L.; Landi, E.; Tampieri, A.; Galassi, C. Dispersing behavior of hydroxyapatite powders produced by wet-chemical synthesis. J. Am. Ceram. Soc. 2003, 86, 1534-1539. [CrossRef]

17. Landi, E.; Tampieri, A.; Celotti, G.C.; Mattioli-Belmonte, M.; Logroscino, G. Synthetic Biomimetic Nanostructured Hydroxyapatite. Key Eng. Mater. 2005, 284-286, 949-952. [CrossRef]

18. Silvester, L.; Lamonier, J.-F.; Vannier, R.-N.; Lamonier, C.; Capron, M.; Mamede, A.-S.; Pourpoint, F.; Gervasini, A.; Dumeignil, F. Structural, textural and acid-base properties of carbonate-containing hydroxyapatites. J. Mater. Chem. A 2014, 2, 11073-11090. [CrossRef]

19. Chlala, D.; Labaki, M.; Giraudon, J.-M.; Gardoll, O.; Denicourt-Nowicki, A.; Roucoux, A.; Lamonier, J.-F. Toluene total oxidation over Pd and Au nanoparticles supported on hydroxyapatite. Comptes Rendus Chim. 2016, 19, 525-537. [CrossRef]

20. Chlala, D.; Giraudon, J.-M.; Nuns, N.; Lancelot, C.; Vannier, R.-N.; Labaki, M.; Lamonier, J.-F. Active Mn species well dispersed on $\mathrm{Ca}^{2+}$ enriched apatite for total oxidation of toluene. Appl. Catal. B Environ. 2016, 184, 87-95. [CrossRef]

21. Boukha, Z.; Kacimi, M.; Ziyad, M.; Ensuque, A.; Bozon-Verduraz, F. Comparative study of catalytic activity of Pd loaded hydroxyapatite and fluoroapatite in butan-2-ol conversion and methane oxidation. J. Mol. Catal. A Chem. 2007, 270, 205-213. [CrossRef]

22. Boukha, Z.; González-Prior, J.; de Rivas, B.; González-Velasco, J.R.; López-Fonseca, R.; Gutiérrez-Ortiz, J.I. Synthesis, characterisation and behaviour of $\mathrm{Co} /$ hydroxyapatite catalysts in the oxidation of 1,2-dichloroethane. Appl. Catal. B Environ. 2016, 190, 125-136. [CrossRef] 
23. Wang, Y.; Chen, B.; Crocker, M.; Zhang, Y.; Zhu, X.; Shi, C. Understanding on the origins of hydroxyapatite stabilized gold nanoparticles as high-efficiency catalysts for formaldehyde and benzene oxidation. Catal. Commun. 2015, 59, 195-200. [CrossRef]

24. Kumar, P.A.; Reddy, M.P.; Ju, L.K.; Phil, H.H. Novel Silver Loaded Hydroxyapatite Catalyst for the Selective Catalytic Reduction of $\mathrm{NO}_{x}$ by Propene. Catal. Lett. 2008, 126, 78-83. [CrossRef]

25. Tounsi, H.; Djemal, S.; Petitto, C.; Delahay, G. Copper loaded hydroxyapatite catalyst for selective catalytic reduction of nitric oxide with ammonia. Appl. Catal. B Environ. 2011, 107, 158-163. [CrossRef]

26. Campisi, S.; Galloni, M.G.; Marchetti, S.G.; Auroux, A.; Postole, G.; Gervasini, A. Functionalized Iron Hydroxyapatite as Eco-friendly Catalyst for $\mathrm{NH}_{3}$-SCR Reaction: Activity and Role of Iron Speciation on the Surface. ChemCatChem 2020, 12, 1676-1690. [CrossRef]

27. Campisi, S.; Galloni, M.G.; Bossola, F.; Gervasini, A. Comparative performance of copper and iron functionalized hydroxyapatite catalysts in $\mathrm{NH}_{3}$-SCR. Catal. Commun. 2019, 123, 79-85. [CrossRef]

28. Schiavoni, M.; Campisi, S.; Carniti, P.; Gervasini, A.; Delplanche, T. Focus on the catalytic performances of $\mathrm{Cu}$-functionalized hydroxyapatites in $\mathrm{NH}_{3}$-SCR reaction. Appl. Catal. A Gen. 2018, 563, 43-53. [CrossRef]

29. Ferri, M.; Campisi, S.; Scavini, M.; Evangelisti, C.; Carniti, P.; Gervasini, A. In-depth study of the mechanism of heavy metal trapping on the surface of hydroxyapatite. Appl. Surf. Sci. 2019, 475, 397-409. [CrossRef]

30. Sakhno, Y.; Bertinetti, L.; Iafisco, M.; Tampieri, A.; Roveri, N.; Martra, G. Surface hydration and cationic sites of nanohydroxyapatites with amorphous or crystalline surfaces: A comparative study. J. Phys. Chem. C 2010, 114, 16640-16648. [CrossRef]

31. Nikolenko, N.V.; Esajenko, E.E. Surface properties of synthetic calcium hydroxyapatite. Adsorpt. Sci. Technol. 2005, 23, 543-553. [CrossRef]

32. Misra, D.N. Adsorption on hydroxyapatite: Role of hydrogen bonding and interphase coupling. Langmuir 1988, 4, 953-958. [CrossRef]

33. Sotomayor, F.J.; Cychosz, K.A.; Thommes, M. Characterization of Micro/Mesoporous Materials by Physisorption: Concepts and Case Studies. Acc. Mater. Surf. Res. 2018, 3, 34-50.

34. Schiavoni, M.; Campisi, S.; Gervasini, A. Effect of $\mathrm{Cu}$ deposition method on silico aluminophosphate catalysts in $\mathrm{NH}_{3}$-SCR and $\mathrm{NH}_{3}$-SCO reactions. Appl. Catal. A Gen. 2017, 543, 162-172. [CrossRef]

35. Campisi, S.; Palliggiano, S.; Gervasini, A.; Evangelisti, C. Finely Iron-Dispersed Particles on $\beta$ Zeolite from Solvated Iron Atoms: Promising Catalysts for $\mathrm{NH}_{3}$-SCO. J. Phys. Chem. C 2019, 123, 11723-11733. [CrossRef]

36. Madia, G.; Koebel, M.; Elsener, M.; Wokaun, A. Side Reactions in the Selective Catalytic Reduction of $\mathrm{NO}_{\mathbf{x}}$ with Various $\mathrm{NO}_{2}$ Fractions. Ind. Eng. Chem. Res. 2002, 41, 4008-4015. [CrossRef]

37. Li, Y.; TeckNam, C.; PingOoi, C. Iron(III) and manganese(II) substituted hydroxyapatite nanoparticles: Characterization and cytotoxicity analysis. J. Phys. Conf. Ser. 2009, 187. [CrossRef]

38. Khachani, M.; Kacimi, M.; Ensuque, A.; Piquemal, J.-Y.; Connan, C.; Bozon-Verduraz, F.; Ziyad, M. Iron-calcium-hydroxyapatite catalysts: Iron speciation and comparative performances in butan-2-ol conversion and propane oxidative dehydrogenation. Appl. Catal. A Gen. 2010, 388, 113-123. [CrossRef]

39. Kandori, K.; Toshima, S.; Wakamura, M.; Fukusumi, M.; Morisada, Y. Effects of Modification of Calcium Hydroxyapatites by Trivalent Metal Ions on the Protein Adsorption Behavior. J. Phys. Chem. B 2010, 114, 2399-2404. [CrossRef]

40. Cornell, R.M.; Schwertmann, U. Chapter 7 Characterization. In The Iron Oxides: Structure, Properties, Reactions, Occurrences, and Uses; Cornell, R.M., Schwertmann, U., Eds.; Wiley-VCH Verlag GmbH \& Co. KGaA: Weinheim, Germany, 1996; pp. 139-183.

41. Long, G.J.; Grandjean, F. Mössbauer Spectroscopy Applied to Inorganic Chemistry; Modern Inorganic Chemistry; Springer: New York, NY, USA, 2013; ISBN 9781489922892.

42. Long, G.J.; Grandjean, F. Mössbauer Spectroscopy Applied to Magnetism and Materials Science; Modern Inorganic Chemistry; Springer: New York, NY, USA, 2013; ISBN 9781489924094.

43. Han, L.; Cai, S.; Gao, M.; Hasegawa, J.Y.; Wang, P.; Zhang, J.; Shi, L.; Zhang, D. Selective Catalytic Reduction of $\mathrm{NO}_{x}$ with $\mathrm{NH}_{3}$ by Using Novel Catalysts: State of the Art and Future Prospects. Chem. Rev. 2019, 119, 10916-10976. [CrossRef]

44. Zhang, R.; Liu, N.; Lei, Z.; Chen, B. Selective Transformation of Various Nitrogen-Containing Exhaust Gases toward $\mathrm{N}_{2}$ over Zeolite Catalysts. Chem. Rev. 2016, 116, 3658-3721. [CrossRef]

45. Kröcher, O.; Brandenberger, S. Active sites, deactivation and stabilization of Fe-ZSM-5 for the selective catalytic reduction (SCR) of $\mathrm{NO}$ with $\mathrm{NH}_{3}$. Chimia 2012, 66, 687-693. [CrossRef] [PubMed] 
46. Brandenberger, S.; Kröcher, O.; Tissler, A.; Althoff, R. The determination of the activities of different iron species in Fe-ZSM-5 for SCR of $\mathrm{NO}$ by $\mathrm{NH}_{3}$. Appl. Catal. B Environ. 2010, 95, 348-357. [CrossRef]

47. Chmielarz, L.; Jabłońska, M. Advances in selective catalytic oxidation of ammonia to dinitrogen: A review. RSC Adv. 2015, 5, 43408-43431. [CrossRef]

48. Heyden, A.; Hansen, N.; Bell, A.T.; Keil, F.J. Nitrous oxide decomposition over Fe-ZSM-5 in the presence of nitric oxide: A comprehensive DFT study. J. Phys. Chem. B 2006, 110, 17096-17114. [CrossRef] [PubMed]

49. Heyden, A.; Peters, B.; Bell, A.T.; Keil, F.J. Comprehensive DFT study of nitrous oxide decomposition over Fe-ZSM-5. J. Phys. Chem. B 2005, 109, 1857-1873. [CrossRef]

50. Lagarec, K.; Rancourt, D.G. Recoil-Mössbauer Spectral Analysis Software for Windows; University of Ottawa: Ottawa, ON, Canada, 1998.

Publisher's Note: MDPI stays neutral with regard to jurisdictional claims in published maps and institutional affiliations.

(C) 2020 by the authors. Licensee MDPI, Basel, Switzerland. This article is an open access article distributed under the terms and conditions of the Creative Commons Attribution (CC BY) license (http://creativecommons.org/licenses/by/4.0/). 